\title{
Upper plate deformation as marker for the Northern STEP fault of the Ionian slab (Tyrrhenian Sea, central Mediterranean)
}

\author{
Alfonsa Milia ${ }^{\mathrm{a}, *}$, Pietro Iannace ${ }^{\mathrm{b}}$, Magdala Tesauro ${ }^{\mathrm{c}}$, Maurizio M. Torrente ${ }^{\mathrm{b}}$ \\ a IAMC, CNR, Calata Porta di Massa, Porto di Napoli, I-80100 Naples, Italy \\ b DST, Università del Sannio, Via dei Mulini 59/A, I-82100 Benevento, Italy \\ c Utrecht University, Budapestlaan, 6, 3584 CD Utrecht, The Netherlands
}

\section{A R T I C L E I N F O}

\section{Article history:}

Received 28 January 2016

Received in revised form 19 August 2016

Accepted 22 August 2016

Available online 24 August 2016

\section{Keywords:}

Backarc extension

Tectono-stratigraphy

$3 \mathrm{D}$ visualization

STEP fault

Tyrrhenian Sea

\begin{abstract}
A B S T R A C T
The Eastern Tyrrhenian margin (ETM), the active boundary of the Tyrrhenian Sea backarc basin, is the key for understanding the geodynamics of the central Mediterranean. Numerous seismic tomography studies have been carried out in this region, proposing different reconstructions of the lower subducting plate and cause of the slab-break-off existing beneath the Southern Apennines. However, the area and mode of the recent deformation of the Tyrrhenian Sea are still not fully defined and understood. In this study, we combine the analysis of a recent seismic tomography model and geological data, in order to understand the relationship between the subducting lower plate and the tectonic evolution of the sedimentary basins formed on the upper plate.

With this aim, we interpreted a large data set of seismic reflection profiles and several well logs. The results consist in 2D and 3D geological models of the basins, sedimentary infill, and fault networks. Taking into account the geological data of the ETM and those of the adjacent inner flank of the Apennines, we observe: (i) a system of linked sedimentary basins developed on a narrow deformation belt bounded by transform fault zones; (ii) a polyphase rifting within the upper plate; (iii) an abrupt change of the direction of extension $\left(\sim 90^{\circ}\right)$, from NE-oriented in the Lower Pleistocene to SE-oriented in the Middle Pleistocene. Since these ETM features are not the typical expressions of the current backarc extensional models, we propose a link between the evolution of upper plate and the onset and development of a STEP (Subduction-Transform-Edge-Propagator) fault along the northern margin of the Ionian slab.
\end{abstract}

(C) 2016 Elsevier B.V. All rights reserved.

\section{Introduction}

Extension in backarc basins plays a central role in the tectonic evolution of many areas of the Earth (e.g. Schellart and Lister, 2005; Cloetingh et al., 2013, 2015). Backarc environments are characterized by rift basins developing in convergent plate boundaries on the concave side of arcs. They are widely spread around the globe with numerous examples in the western Pacific and Mediterranean Sea (e.g. Taylor, 1995; Faccenna et al., 1996). The Tyrrhenian Sea is the youngest backarc basin of the Western Mediterranean linked to development of the Ionian subduction zone (Fig. 1). The Eastern margin of the Tyrrhenian Sea (Eastern Tyrrhenian Margin, ETM) is characterized by the opening of the youngest sedimentary basins and fault activity. Studying the tectonic Quaternary evolution of the ETM greatly improves our understanding of the geodynamics of the Central Mediterranean, since it records the mode of extension of a backarc migration toward the continental area and is located in correspondence of the northern boundary of the Ionian

\footnotetext{
* Corresponding author.

E-mail addresses: alfonsa.milia@iamc.cnr.it (A. Milia), piannace@unisannio.it (P. Iannace), m.tesauro@uu.nl (M. Tesauro), torrente@unisannio.it (M.M. Torrente).
}

subducting plate. Such a study makes it also possible to identify the causes of the present-day tectonics, which is of primary societal interest, as this region is densely populated. Furthermore, the ETM is characterized by recent volcanic activity (e.g., Vesuvius and Campi Flegrei) and thus has a large potential of geo-resources, such as mineral deposits and geothermal energy (e.g. De Vivo et al., 1989; Serri, 1990; Bodnar et al., 2007; Lima et al., 2009; Milia, 2010; Milia and Torrente, 2011; Carlino et al., 2012).

Seismic tomography studies of the central Mediterranean (e.g. Wortel and Spakman, 2000) revealed an extended high-velocity zone interpreted as the subducting Adriatic and Ionian slab. The continuity of the Adriatic slab is interrupted, as observed form the low velocity zones located in the uppermost part of the mantle underlying the southern Apennines. The existence of a gap in the structure of the subducted slab, interpreted as a slab detachment, was postulated already in 1971 by Isacks and Molnar (Isacks and Molnar, 1971). Afterwards, Wortel and Spakman (2000) and Govers and Wortel (2005) hypothesized a lateral migration of the slab detachment due to tears formation. These authors suggested that the slab edges correspond to Subduction Transform Edge Propagator (STEP) faults, characterized by a very specific time-space evolution in the upper plate deformation. Govers and 

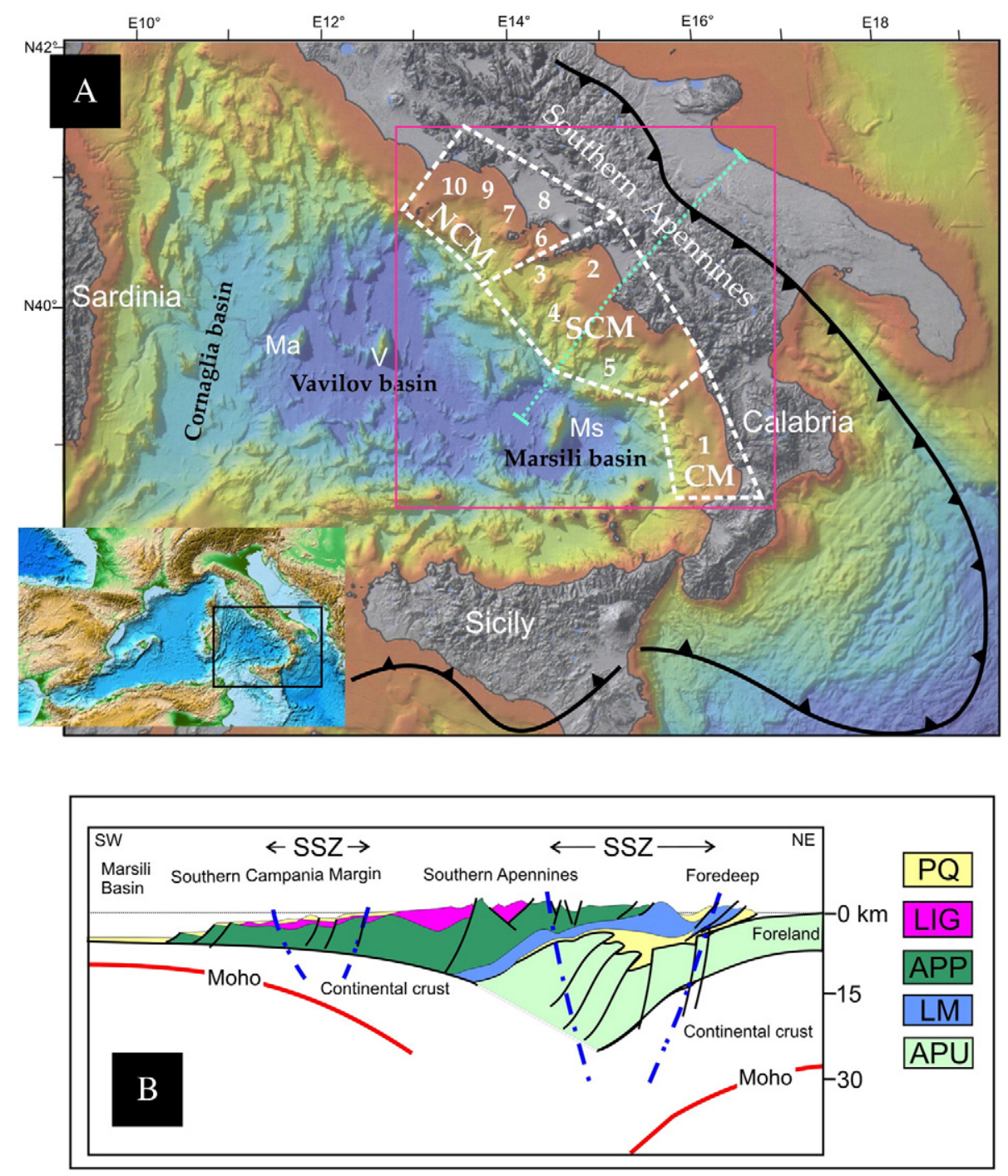

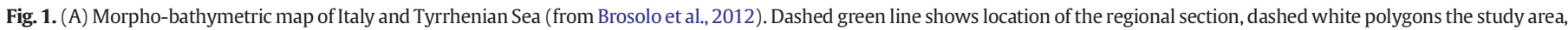

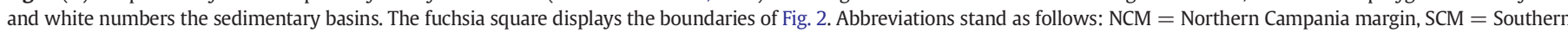

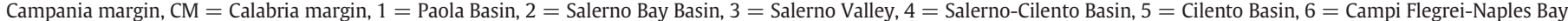

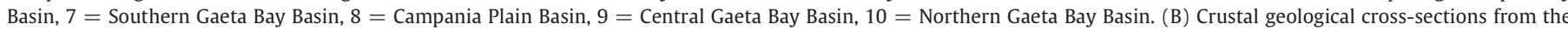

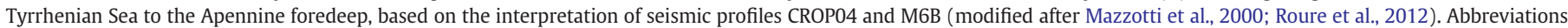

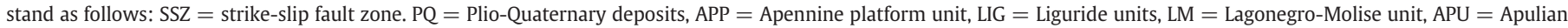
platform unit.

Wortel (2005) hypothesize the presence of STEP fault as boundary of narrow subducting oceanic plates locked by continental crust. One of these examples is in the Mediterranean region, where the Ionian slab may have two STEP faults in the northern and southern parts. In this case whereas the southern STEP fault is well represented by the E-W boundary between the Africa and backarc margin (e.g. Carminati et al., 1998; Gvirtzman and Nur, 1999; Argnani, 2009), the deformation zone linked to the northern STEP fault of the Ionian slab is poorly constrained (e.g. Gvirtzman and Nur, 1999; Marani and Trua, 2002; Govers and Wortel, 2005; Lucente et al., 2006; Rosenbaum et al., 2008).

The stratigraphic and tectonic study of the sedimentary basins located on the upper plate provides constraints on the timing and duration of the rifting phases and overall geometry of rift basins that evolve in response to the subducting slab dynamics. Within this frame, the analysis of this sedimentary basin gives fundamental constraints on the reconstruction of the geodynamic evolution and clarifies the relationships between deep and shallow structures in convergent regions.

The development of software for 3D modeling has opened a new frontier in Earth Sciences, leading to a more accurate spatial analysis of geological structure and to 3D models. Numerous papers deal with the integration of different kind of data for a 3D reconstruction of subsurface structures at a regional scale (e.g., De Donatis, 2001; D'Ambrogi et al., 2004; Dhont et al., 2005; Smith, 2005; Bigi et al., 2013). The subsurface data generally used for 3D reconstructions are the seismic data, integrated with well data logs. Several deep sedimentary basins that are present along the Eastern Tyrrhenian Margin have been studied separately (e.g., Sacchi et al., 1994; Milia, 1999; Milia et al., 2009, 2013) and thus a synthesis of the relationships among each stratigraphic unit between these extensional basins and a complete analysis of the fault pattern is lacking so far. In this study we construct a 3D model, providing the detailed structure of the Tyrrhenian margin, impossible to obtain with only 2D seismic dataset. The results obtained by integrating multi-source data (seismic reflection profiles and boreholes), greatly improves our understanding of the geological structures of the study area.

The analysis of the crustal deformation of the Southern Campania Margin, coupled with a review of the Northern Campania Margin basins and Paola Basin makes it possible to identify: a) the area of the 
youngest deformation of the Tyrrhenian Sea; b) the genetic link between the deep and rapidly evolving sedimentary basins; c) the kinematic evolution of the study region. In addition, using the results of this analysis and of the recent regional seismic tomography model of Koulakov et al. (2009), we propose a model of the tectonic evolution of the area, finding a link between the shallow and deep structures.

\section{Geologic framework}

The Western Mediterranean is characterized by a complex pattern of backarc basins in response to migration of the Calabria subduction zone (Dewey et al., 1989; Mauffret et al., 2004). The formation of these backarc basins starts with the opening of the Liguro-Provencal basin, between 30 and $16 \mathrm{Ma}$ (Cherchi and Montadert, 1982; Burrus, 1984; Séranne, 1999), followed by the Algerian Basin, between 16 and $7 \mathrm{Ma}$ (van Hinsbergen et al., 2014), and finally the Tyrrhenian basin, between $12 \mathrm{Ma}$ and the Present (e.g. Kastens et al., 1987; Sartori, 1990; Milia and Torrente, 2014).

The tomographic studies of the deep structure of the Tyrrhenian-Apennine system and the distribution of subcrustal earthquakes (e.g. Frepoli et al., 1996; Anderson and Jackson, 1987; Cimini and De Gori, 2001) reveal the occurrence in the southern Tyrrhenian sea of a Benioff zone, associated to the subduction of the Ionian plate below Calabria, that dips northwestwards from the surface down to $500 \mathrm{~km}$. Furthermore, it has been suggested that a rollback subduction of the Calabrian slab induced a local scale mantle flow parallel to the trench (Gvirtzman and Nur, 1999; Civello and Margheriti, 2004; Faccenna et al., 2007).

The geophysical data reveal that the Southern Apennine fold-andthrust belt covers the autochthonous Apulian continental crust, 25$30 \mathrm{~km}$ thick (Mostardini and Merlini, 1986; Menardi-Noguera and Rea, 2000; Roure et al., 1990). In contrast, the Calabria terrane overthrusts the oceanic Ionian crust, considered a late Paleozoic-Early Mesozoic oceanic embayment of the Neothetys (Catalano et al., 2001; Stampfli and Borel, 2004). The oceanic nature of the Ionian crust has been also confirmed by seismic refraction data (de Voogd et al., 1992).

The Tyrrhenian Sea, at the rear of the Apennine fold-and-thrust belt is a typical rift basin, characterized by a thinned lithosphere $(<30 \mathrm{~km})$ and continental crust, with a Moho depth $<10 \mathrm{~km}$ in the bathyal plain and $\sim 20 \mathrm{~km}$ along its Eastern margin (Ferrucci et al., 1989; Nicolich, 1989; Panza, 1984), numerous normal faults, large Bouguer anomalies (>250 mGal in the bathyal plain; Mongelli et al., 1975), and high heat flow values (up to $200 \mathrm{~mW} \mathrm{~m}^{-2}$; Della Vedova et al., 2001). The features recognized in the bathyal area also occur in the Campania Margin characterized by high heat flow values and shallow Moho reaching $10 \mathrm{~km}$ at Campi Flegrei (Ferrucci et al., 1989).

The hinge zone between the Southern Apennine/Calabria fold thrust belt and the bathyal area of the Tyrrhenian Sea corresponds to the Eastern Tyrrhenian Continental Margin, subdivided into Northern Campania Margin (NCM), Southern Campania Margin (SCM), and Calabria Margin (CM) (Fig.1).

The NCM is characterized by the presence of up to $5 \mathrm{~km}$ deep basins filled by Quaternary clastic and volcaniclastic deposits (Ippolito et al., 1973; Rosi and Sbrana, 1987; Mariani and Prato, 1988; Milia, 1999; Milia et al., 2003). The NCM is affected by NE-SW, NW-SE, NNE-SSW and E-W faults. It started to form in the Lower Pleistocene and is characterized by the superposition of the three extensional events (Milia and Torrente, 1997, 1999, 2011, 2015b; Bellucci et al., 2006; Torrente et al., 2010; Milia et al., 2013).

The SCM has been studied by few authors who have investigated mainly the continental shelf area (Bartole et al., 1984; Sacchi et al., 1994; Casciello et al., 2004). Previous studies of Salerno Bay suggest that NE-trending normal faults controlled a thick depocenter $(>2 \mathrm{~km}$, Mina 1 well) of the basin (Bartole et al., 1984; Sacchi et al., 1994; Casciello et al., 2004). The age of these syn-rift deposits is controversial, Pliocene-Pleistocene according to Bartole et al. (1984) and Sacchi et al.
(1994) or Pleistocene according to Casciello et al. (2004). The Sele Plain, onshore extension of the Salerno Bay, is characterized by a Pleistocene clastic succession up to 1500 m-thick (Sele 1 well), showing at the base lower Pleistocene conglomerates (Eboli Fm; Cinque et al., 1988; Russo, 1990; Brancaccio et al., 1991), displaced by NW-SE and NE-SW normal faults (Gars and Lippmann, 1984; Zuppetta and Sava, 1992).

The CM is characterized by the Paola Basin, which has a very thick Plio-Quaternary succession (> 4 km, Fabbri et al., 1981), affected by Quaternary folding (Argnani and Trincardi, 1988). Recently, Milia et al. (2009) proposed a poliphased tectonic evolution of the Paola Basin superimposed to a Serravallian E-W extension: Lower Pleistocene N-S extension (basin formation), followed NW-SE left lateral strike slip tectonics with associated folding, and Middle-Late Pleistocene NW-SE right-lateral strike slip tectonics (minor pull-apart basins).

Two main tectonic scenarios have been proposed for this backarc basin:

(1) An approximately E-W direction of extension, as suggested by fault patterns, which controlled the opening of extensional sedimentary basins since the Upper Miocene. This extension direction is orthogonal to Apennine foredeeps and coherent with the eastwards migration of the Adria-Apennine trench (Sartori, 1989; Patacca et al., 1990; Doglioni, 1991). The contemporaneous formation of the Tyrrhenian Sea and Apennine thrust belt migrating eastwards, lead Patacca et al. (1990) to propose a genetic link between the extensional and compression tectonics (Fig. 1b). Extension in the Tyrrhenian Sea and shortening in the Apennine thrust belt, as a result of arc migration (rollback) driven by the sinking of the lithosphere, was the mechanism invoked by Malinverno and Ryan (1986). Doglioni (1991), and more recently Roure et al. (2012), interpreted the E-W opening of the Tyrrhenian Sea until the Pliocene/Lower Pleistocene and the contemporaneous shortening of the Apennines with a model of the West-dipping subduction of the Adriatic-Ionian slab beneath the Tyrrhenian Sea. This model of evolution includes the presence of E-W transform faults across the Tyrrhenian Sea (Selli, 1981; Lavecchia, 1988; Rosenbaum and Lister, 2004; Finetti and Del Ben, 2005).

(2) Opening of the Tyrrhenian backarc basin toward SE, as indicated by the age of the oldest sediments drilled and by the sparse data of the DSDP and ODP in the bathyal area, linked to the rollback of the Ionian slab toward SE, as imaged by the tomographic models (e.g. Cavinato and De Celles, 1999; Gvirtzman and Nur, 1999; Wortel and Spakman, 2000; Faccenna et al., 2004, 2007; van Hinsbergen et al., 2014). Furthermore, the entire southern Apennine thrust belt is characterized by a system of NW-SE trending left-lateral strike-slip fault zones post-LowerMiddle Pleistocene in age (Fig. 1b; Catalano et al., 1993, 2004; Cinque et al., 1993; Schiattarella et al., 2005). This geodynamic scenario of a NW-SE opening of the Tyrrhenian Sea is consistent with a NW-SE sinistral transform fault located on the eastern Tyrrhenian margin (Wortel and Spakman, 2000; Marani and Trua, 2002).

Based on the tectono-stratigraphic evolution of the overfilled sedimentary basins located on the eastern margin of the Tyrrhenian Sea, a different and more complex evolution of the backarc opening has been recently proposed. Since the Serravallian stage, extension of backarc and forearc was directed toward the East and affected by a widespread area of the central Mediterranean (Paleo-Tyrrhenian Sea) (Milia and Torrente, 2014). During the Messinian stage a dramatic increase in the extension rates occurred (Milia and Torrente, 2015a) with formation of supradetachment basins (sensu Friedman and Burbank, 1995). During the Pliocene-Lower Pleistocene time the contemporaneous opening of three sedimentary basins with different direction of extension (Vavilov, Marsili, and Paola Basins) affected the Southern Tyrrhenian Sea, suggesting a mechanism of double-saloondoor model (Milia et al., 2013; Milia and Torrente, 2015b). Successively, from the Middle Pleistocene, a progressive change in the migration of extension occurred on the Eastern Tyrrhenian Margin (Milia and Torrente, 1999, 2011, 2015b). 

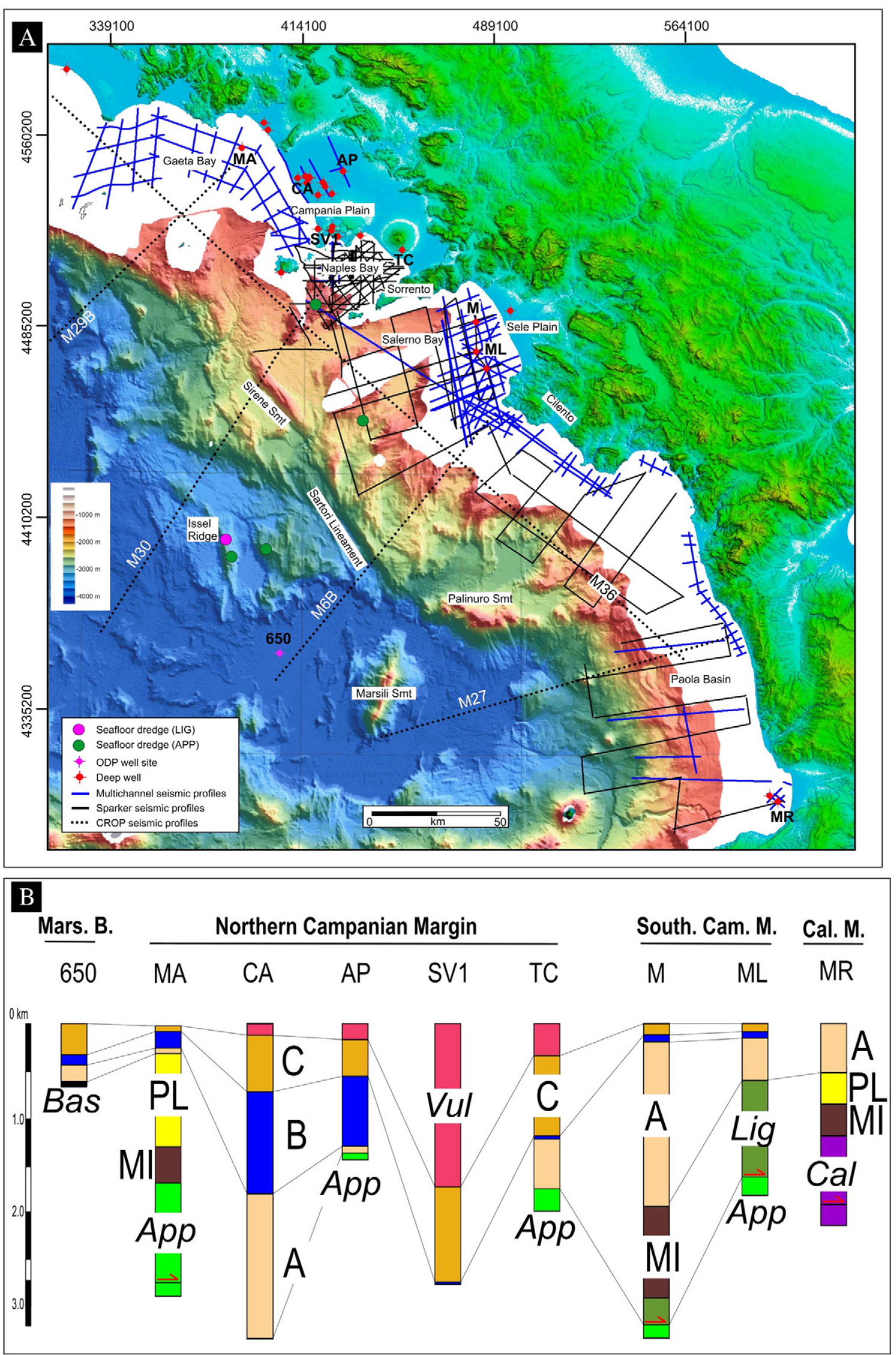


\section{Data and methods}

We constructed a 3-D subsurface model of the basin's basement of the eastern Tyrrhenian margin generated through the interpolation between close and regularly spaced 2D seismic reflection profiles, integrated and calibrated with borehole data (Fig. 2). This work has been carried out using a seismic and borehole dataset and a Geographical Information System (GIS) software (Kingdom, IHS Inc.), which constructs a 3D representation of a geologic volume at depth. This study was carried out through the following steps: a) collection of all the available seismic profiles and boreholes data; b) implementation of a GIS geological data base; c) interpretation of the seismic profiles and calibration of the seismic unit using well-log data; d) construction of $2 \mathrm{D}$ and $3 \mathrm{D}$ models of the subsurface.

A total of $6000 \mathrm{~km}$ of seismic lines and data from 25 wells were collected in the study area (Fig. 2). We used seismic reflection profiles with different resolution and penetration: multichannel seismic profiles (ViDEPI, 2009), CROP seismic profiles (Scrocca et al., 2003) and Sparker data. Our study uses $1050 \mathrm{~km}$ of CROP offshore seismic sections of the eastern Tyrrhenian margin (Fig. 2). The Sparker seismic data set was acquired with a Multispot Extended Array System (MEAS). The output power of the MEAS, transmitted through a 36-tip array, was $16 \mathrm{~kJ}$. Vertical recording scales were $2.0 \mathrm{~s}$ with a maximum vertical resolution of $6 \mathrm{~m}$. The data were subsequently processed in order to obtain a consistent dataset: seismic line basemaps and well position were geo-referenced in a common coordinate system (European Datum 50) and assembled in a dedicated GIS environment (Kingdom, IHS Inc.). Raster images of the overall seismic profiles were converted to segy format using image2segy, a free tool developed by Marcel Farran (Instituto de Cièncias del Mar., Barcelona University) for MATLAB software.

We interpreted the seismic data-set using the seismic stratigraphy method: seismic units are groups of seismic reflections, whose parameters (configuration, amplitude, continuity, and frequency) differ from those of adjacent groups. Sedimentary units were delineated on the basis of contact relations and internal and external configurations (e.g. Mitchum et al., 1977). The seismic units were calibrated using the lithostratigraphic and chronostratigraphic data of offshore and onshore boreholes (Ippolito et al., 1973; Rosi and Sbrana, 1987; ViDEPI, 2009; Brocchini et al., 2001). Based on seismic facies, well data analysis and dated units, three unconformitybounded units have been identified (Unit A, Unit B, Unit C) in the basin infills. Notably, we placed in our stratigraphic analysis the base of the Pleistocene at the base of the Gelasian stage (2.58 Ma), in agreement with the "Global chronostratigraphical correlation table for the last 2.7 million years v. 2010" (Cohen and Gibbard, 2010). Thus, the Gelasian succession of the Eastern Tyrrhenian margin, previously attributed to the upper Pliocene, has been ascribed to the lower Pleistocene. Faults were interpreted on seismic reflection profiles, mapped in a GIS environment, and displayed as lines on structure contour maps and isochron maps. Due to a relatively close spacing between 2-D seismic lines (1-10 km in NCM, 3$15 \mathrm{~km}$ in SCM, 5-10 km in CM), it was possible to recognize and link major faults based on their geometry, dip direction and amount of throw.

Gridding and contouring were performed on geological horizons to generate 2D models (contour maps) and isochron maps of the succession. In order to select the best algorithm and processing parameters, iterative testing was carried out. The final step was the construction of the 3D digital model using the Vu-PACK module (Kingdom software) that permits more accurate interpretations and controls opacity, color, and lighting of volumes, horizons and faults.

\section{Stratigraphy}

In order to define the stratigraphic setting of the Eastern Tyrrhenian Margin, we interpreted a large data set of seismic and wells collected in the Southern Campania Margin and revised the available geological data in the Northern Campania and Calabria margins. We mapped the preQuaternary basement and three stratigraphic units (A, B, C) of the basin infills for $350 \mathrm{~km}$ along the ETM, to establish a coherent chronostratigraphic framework across the sedimentary basins and to build a 3D model of the study area.

\subsection{Basement}

In the NCM, the acoustic basement features reflection-free and chaotic seismic facies (Figs. 3, 4). It is composed of Meso-Cenozoic carbonate rocks forming the Apennine Platform unit of the thrust belt. These rocks have been drilled in the Mara, Apramo and Trecase wells, dredged offshore Naples Bay and outcrop in the mountains bounding the Campania Plain and the Gaeta Bay (Fig. 2) (Milia, 1999; Milia and Torrente, 1999, 2015b; Milia and Torrente, 2011; Milia et al., 2013).

In the SCM, the acoustic basement corresponds to three seismic units calibrated by wells (Fig. 5): a reflection-free seismic unit bounded at the top by strong reflectors (Mz), a chaotic seismic facies unit (Lc), and a seismic unit with strong reflectors $(\mathrm{Cg})$. Units $\mathrm{Mz}$, Lc and $\mathrm{Cg}$ correspond, respectively, to Mesozoic rocks of the Apennine Platform unit, overthrusted by Cenozoic rocks of the Liguride basinal units (Nord-Calabrese and Parasicilide units; Bonardi et al., 1988; Mauro and Schiattarella, 1988; Bonardi et al., 2009; Vitale et al., 2011), unconformably overlain by the Cilento Group (Amore et al., 1988; Cavuoto et al., 2004). This basement has been encountered in the offshore wells (Mina 1, Milena 1 and Margherita Mare 1; Fig. 2), dredged in the Salerno through and the Issel ridge (Sartori, 2005), and crop out in the mountains bounding the Sele Plain (Fig. 2). The Liguride units are composed of highly deformed clays, marls, sandstones with some levels of limestones Paleocene-Lower Miocene in age (Lc), whose thickness increases from northwest to southeast. They are overlain by Langhian-Lower Tortonian clays, marls, conglomerates and chalky limestones of the Cilento Group (Cg).

The acoustic basement of the $\mathrm{CM}$ shows reflection-free seismic facies (Fig. 6) and is made up of high-grade metamorphic and intrusive rocks, Paleozoic in age. This basement is covered by Serravallian-Messinian deposits, characterized by high-amplitude and continuous reflectors, that record the oldest stages of the Paleo-Tyrrhenian opening (Milia et al., 2009; Milia and Torrente, 2014).

The contour map and the 3-D model of the basement (Figs. 7, 8), along the Eastern Tyrrhenian Margin, reveal a complex architecture due to the occurrence of several fault sets (NW-SE, NE-SW, E-W and NNE-SSW). Thus, this basement presents several structural depressions with associated basins up to 5/6 km-deep, from North to South: Northern Gaeta Basin (NGB), Central Gaeta Basin (CGB), Campania Plain Basin (CPB), Southern Gaeta Basin (SGB), Campi Flegrei-Naples Bay Basin (CFNB), Salerno Bay Basin (SBB), Salerno Valley Basin (SVB), SalernoCilento Basin (SCB), Cilento Basin (CB), Sapri Basin (SB) and Paola Basin (PB).

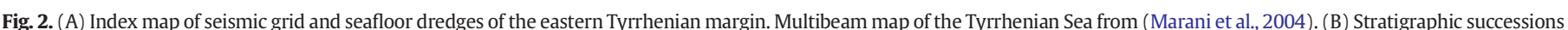

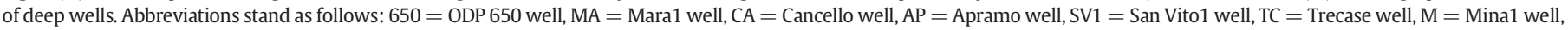

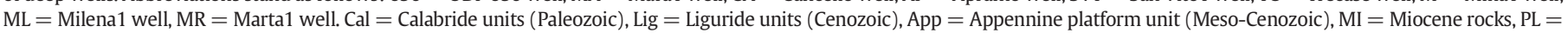
Pliocene rocks, Bas = basalts, $A=$ Unit A, B = Unit B, C = Unit C, V = volcanics (Quaternary), red arrow = thrust fault. See text for further explanation. 

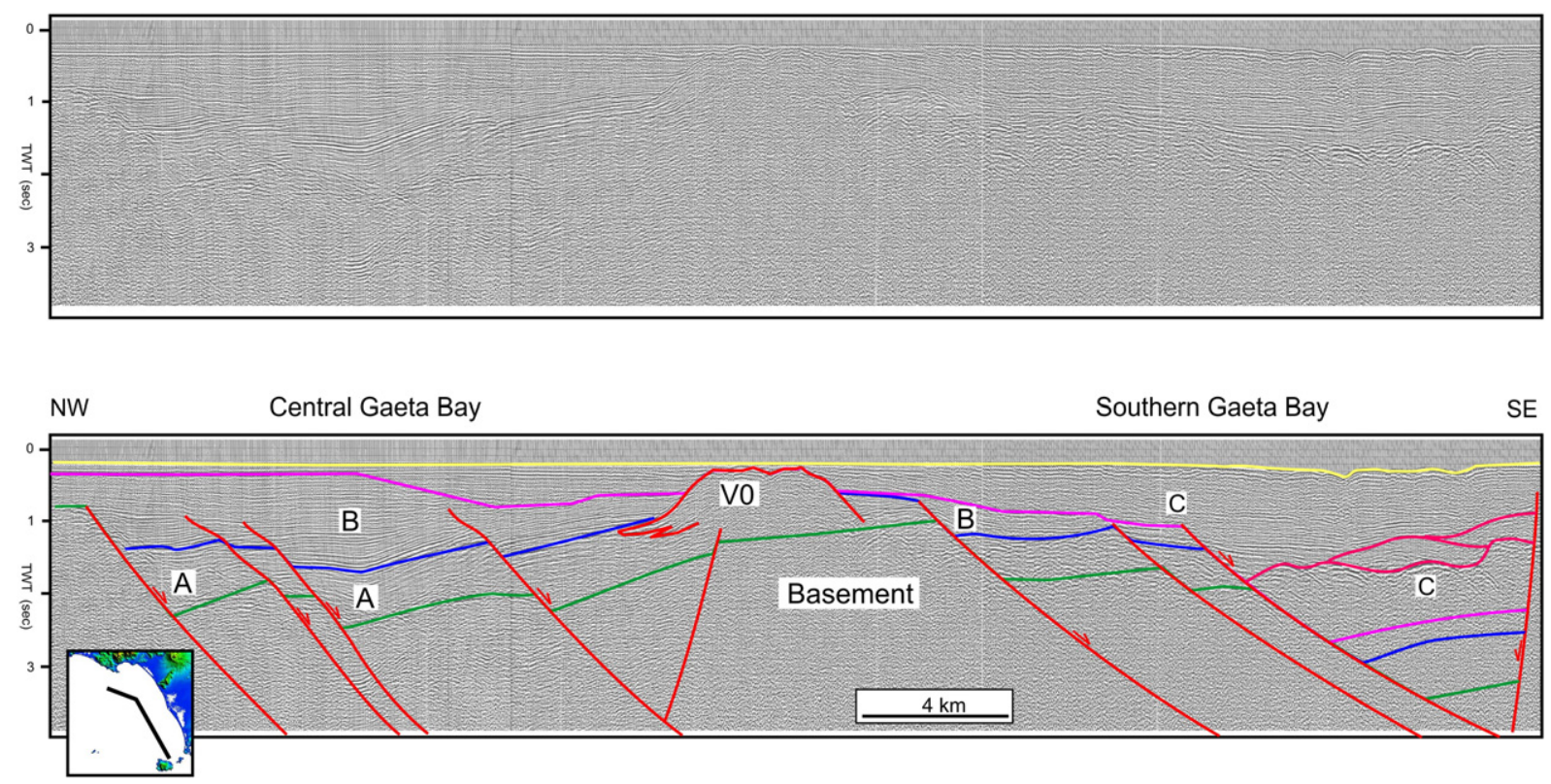

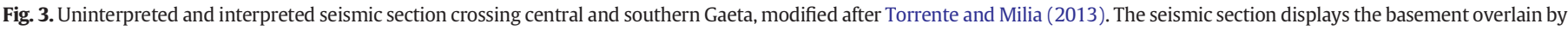
units A, B, and C and several normal faults. V0 corresponds to a lower Pleistocene volcano.

\subsection{Unit A (Lower Pleistocene)}

Unit A overlies the basement and has been dated Lower Pleistocene on the base of well logs stratigraphy, outcrop data and sequence stratigraphy. It has been identified in the Gaeta Bay basins (Iannace et al., 2013; Milia et al., 2013), Campania Plain basin (Milia and Torrente, 2015b), Campi Flegrei-Naples Bay basin (Milia, 1999; Milia and Torrente, 1999, 2011; Milia et al., 2003) and Paola Basin (Milia et al., 2009).

In the NCM this unit is characterized by parallel reflectors with variable amplitude and frequency and very good continuity seismic facies
(Figs. 3, 4). This seismic facies corresponds to shallow-water marine deposits (Milia, 1999; Milia et al., 2003; Milia and Torrente, 2015b). Unit A is characterized by an aggradational stacking pattern and its lower boundary corresponds to an onlap surface, whereas its upper boundary to an erosional one.

We identified unit A for the first time in the SCM. It occurs in a widespread area, covers unconformably the Cenozoic tectonic unit and is wedge-shaped (Fig. 5). Unit A is characterized by parallel and/or subparallel internal reflections configuration, with high to moderate amplitude, good to moderate continuity and an increase of reflectors frequency upwards. Unit A, drilled in Mina 1 and Milena 1 wells (Fig. 2), has a

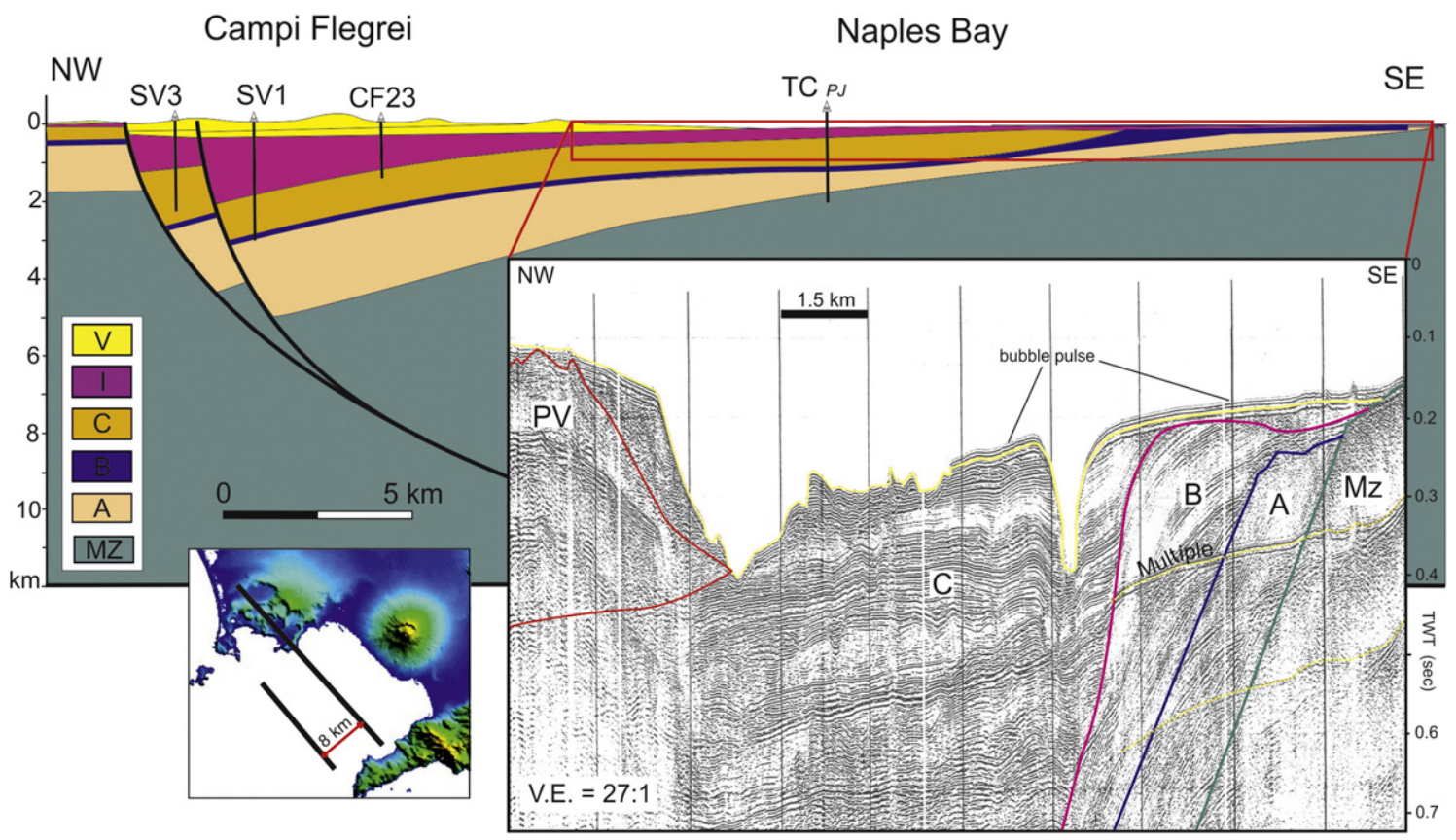

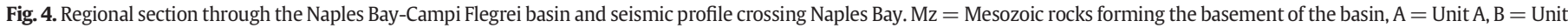
$\mathrm{B}, \mathrm{C}=$ Unit C, PV = Penta Palummo volcano.

Modified from Milia (1999); Milia and Torrente (2011) 


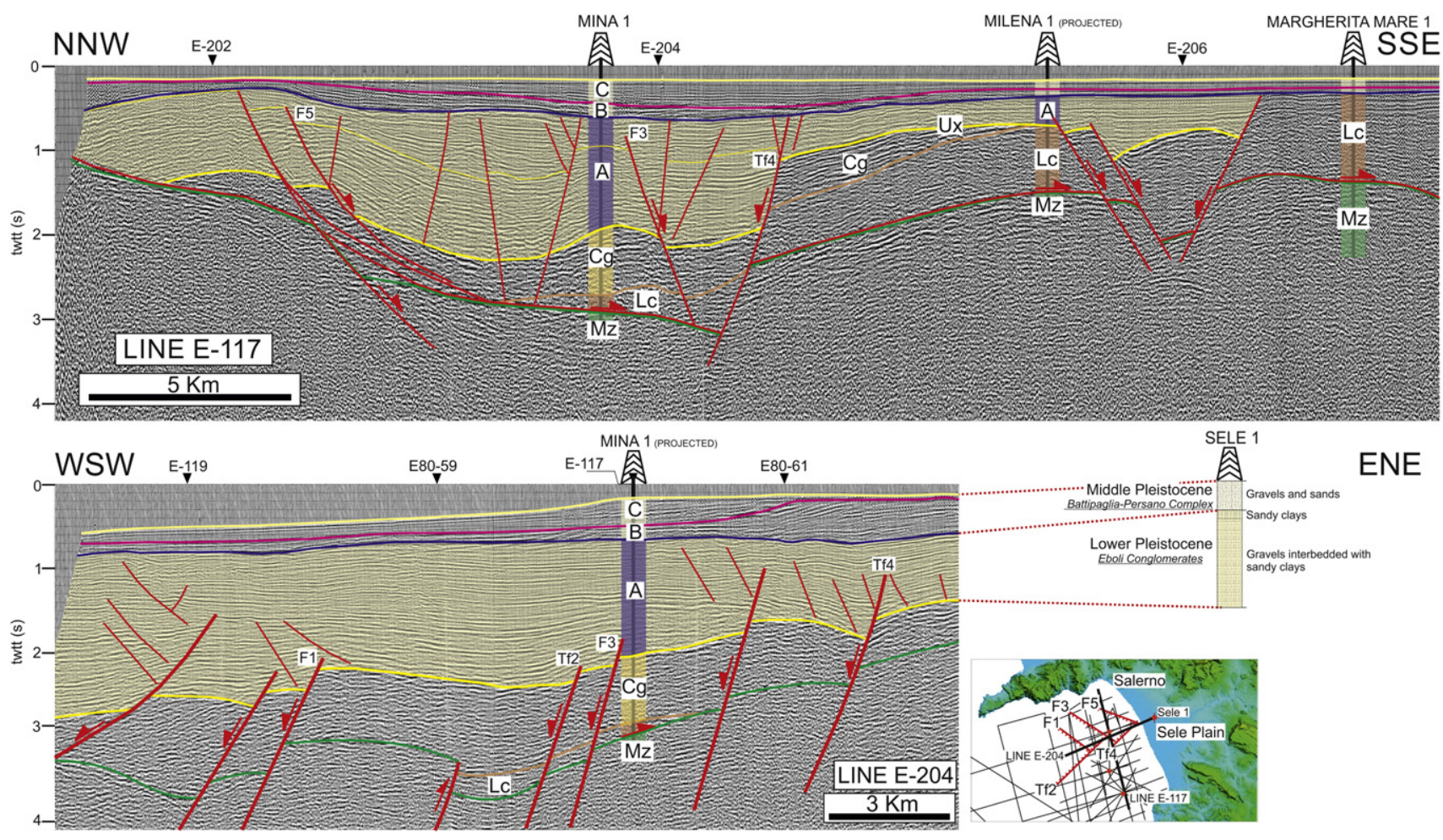

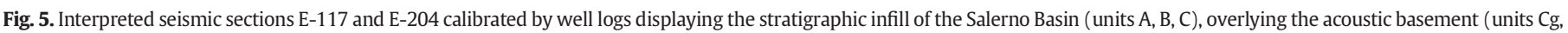
Lc and Mz). Thrust faults, normal faults (F1, F3, F3) and transfer faults (Tf2, Tf4) are also shown.

Lower Pleistocene age (biozone MPL6) and is composed of silty clays, marly clays, marls interbedded with fine sands and polygenic conglomerates, and abundance of carbonaceous materials. These deposits pass upwards to gravels interbedded with sandy clays, marly clays and fine sands and abundance of carbonaceous materials (Sele 1 and Mina 1 wells) Lower Pleistocene in age (biozone post-MPL6). According to our interpretation, Unit A was deposited in Southern Campania Margin between 2.3 and $0.7 \mathrm{Ma}$ and its sedimentary facies changed from coastal shallow-water environment sediments to shelf environment. This stratigraphic evolution witnesses a syn-sedimentary tectonic subsidence.

Unit A is made up of parallel reflectors with aggradational stacking pattern and reaches a thickness of $2.5 \mathrm{~s}$ in the CM (Fig. 6). The age of this unit, drilled in the Marta well (Fig. 2), is Pliocene-Lower Pleistocene. Its upper part displays a wedge-shaped external form thickening toward E/NE. Stratal architecture, growth fold geometry and slumps suggest a syn-sedimentary deformation. According to the sequence stratigraphic analysis of Milia et al. (2009) the age of the syn-sedimentary wedge is $1.0-0.7 \mathrm{Ma}$.

The isochron map of the Unit A (Fig. 9) features seven thickness maxima ( $>1.5 \mathrm{~s}$, twtt): four in the NCM (Northern Gaeta Basin and Central Gaeta Basin, Campania Plain, Campi Flegrei-Naples Bay basin); two in the SCM (Salerno Bay basin and Cilento basin) and one in the CM (Paola basin). These fault-bounded basins are characterized by high sediment supply and depositional rates that balanced the tectonic subsidence.

\subsection{Unit B (Early Middle Pleistocene)}

Unit B is the intermediate part of the Quaternary succession of the Eastern Tyrrhenian Margin and was dated 0.7-0.4 Ma using well logs stratigraphy, outcrop data, and sequence stratigraphy. It has been previously identified in the NCM (Gaeta Bay basin, Iannace et al., 2013; Milia et al., 2013; Campania Plain basin, Milia and Torrente, 2015b; Campi
Flegrei-Naples Bay basin, Milia, 1999; Milia and Torrente, 1999, 2011; Milia et al., 2003) and CM (Paola Basin, Milia et al., 2009). Its stratal architecture, with the exception of the Paola Basin, shows progradational stacking patterns. In the Northern Gaeta Basin Unit B corresponds to a 0.8 s-thick sigmoid-oblique prograding complex that covers the subhorizontal strata of Unit A, suggesting the infill of an undeformed basin. Instead, in the Campi Flegrei-Naples basin Unit B overlies an angular unconformity at the top of the tilted Unit A (Fig. 4). The stratal pattern, facies architecture, and thickness of unit B in the Campania Plain suggest a rapid tectonic subsidence of the area. The normal faults, that caused this basins subsidence, trend NE-SW.

In the CM the sediments coeval to Unit B reveal a dramatic change in the basin fill (Fig. 6): (i) basal onlap surface indicating an abrupt modification in the stratigraphic architecture occurred at the $0.7 \mathrm{Ma}$ sequence boundary; (ii) distal stratal terminations of Unit B onlapping the flank of the fold and filling of the synformal basin; (iii) parallel seismic configuration indicating a horizontal filling of the basin as younger strata thin toward the coast suggesting an uplift of the coastal area.

We identified Unit B for the first time in the SCM, where is characterized by a complex sigmoid-oblique progradational configuration with high to moderate amplitude, moderate frequency and good continuity reflections. This unit, drilled in the Sele 1, Mina 1 and Milena 1, Margherita Mare 1 wells, reposes on the sub-horizontal strata of the Unit A, indicating sediments aggradation/progradation from the coast during a relative tectonic stability of the area (Fig. 5). It is composed of gravels, sands, clays and marly clays Middle Pleistocene in age. In contrast, in the deep basin, Unit B shows a parallel and/or sub-parallel internal reflections configuration, with variable amplitude and frequency and good-continuity reflections (Fig. 10). This seismic facies indicates the deposition of pelagic/hemipelagic sediments interbedded with turbidites. The reflectors are convergent southeastwards, suggesting a fault controlled block tilting. The isochron map of the Unit B shows several thickness maxima (Fig. 11). 

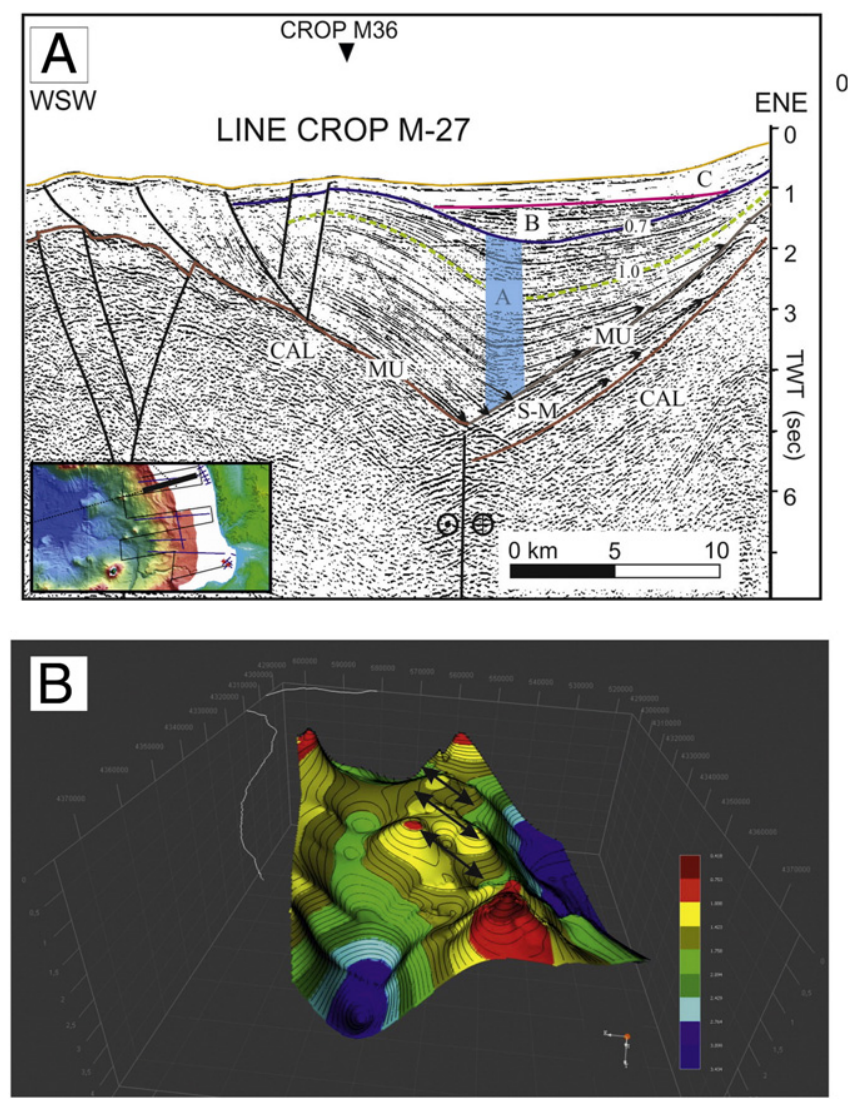

Fig. 6. a) Interpreted seismic section CROP M27 crossing the Paola basin. CAL = Paleozoic crystalline rocks; $\mathrm{SM}=$ Serravallian-Messinian clastics; $\mathrm{MU}=$ Messinian Unconformity, $\mathrm{A}=$ Unit A, DS $1.0=$ Depositional Sequence $1.0, \mathrm{~B}=$ Unit $\mathrm{B}, \mathrm{C}=$ Unit $\mathrm{C}$. The architecture of the syn-sedimentary folds reveals that the lower part of Unit A (below DS 1.0) is pre-kinematic, the upper part of unit A is syn-kinematic and units B and C are post-kinematic (modified from Milia et al., 2009). b) The 3-D digital model inserted into the spatial-oriented grid of the 1.0 surface displaying a main synform coupled with en échelon antiforms (black-arrowed lines) The white line corresponds to the Calabrian coast. View is toward the South.

\subsection{Unit C (Late Middle Pleistocene to present)}

Unit $C$ represents the upper part of the Quaternary succession of the Eastern Tyrrhenian Margin and was dated post-0.4 Ma on the base of well logs stratigraphy, outcrop data and sequence stratigraphy. It has been formerly identified in the NCM (Gaeta Bay basin, Iannace et al., 2013; Milia et al., 2013; Campania Plain basin, Milia and Torrente, 2015b; Campi Flegrei-Naples Bay basin, Milia, 1999; Milia and Torrente, 1999, 2011; Milia et al., 2003) and CM (Paola Basin, Milia et al., 2009). We recognized Unit $C$ for the first time in the SCM.

Along the ETM Unit C displays two different architectures: prograding units filling pre-existing accommodation space and syn-tectonic wedges related to different stages of subsidence. The Northern and Central Gaeta basins and the Salerno Bay and Salerno-Cilento basins are characterized by a thick regressive succession, featuring high-continuity reflectors with variable amplitude and progradational architecture. This seaward lateral migration of the sedimentary deposition that covers the sub-horizontal top of Unit A, indicates a period of relative tectonic stability (Fig. 5).

In the Southern Gaeta Bay and Campania Plain basins a post- $0.4 \mathrm{Ma}$ thick succession of clastic deposits and volcanics (Fig. 3) was emplaced during fault activity (Bellucci et al., 2006; Milia et al., 2006; Torrente et al., 2010; Torrente and Milia, 2013; Milia and Torrente, 2015b). The isochron map of Unit C (Fig. 12) features two striking depocenters ( $>2 \mathrm{~s}$, twtt) filled by voluminous volcanic units in the Southern Gaeta Bay and Campi Flegrei basins. In contrast, others thickness maxima (up to $1 \mathrm{~s}$, twtt), roughly parallel to the coast, exist in the Northern Gaeta Bay-Central Gaeta Bay area and offshore Cilento, reflecting the shelf margin of the coastal progradation. During the deposition of the Unit $\mathrm{C}$ the Paola Basin experienced the deposition of a relatively thick slope front fill unit.

\section{Tectonics}

The interpretation of the seismic data reveals a complex fault pattern along the Eastern Tyrrhenian Sea due to a polyphase tectonic evolution. The 2-D and 3-D models of stratigraphic surfaces, faults and isochron maps of the stratigraphic units reveal that the major faults bounding the basins correspond to normal faults and strike-slip transfer faults (Figs. 7-9, 11-12). The process of lithospheric extension within the Eastern Tyrrhenian Sea produced tilted blocks/half grabens (sensu Wernicke and Burchfiel, 1982). Active extensional faulting and sedimentation are intimately linked during basin evolution because tectonics controls the creation of the accommodation space, sediment supply and variation of the ratio between subsidence and sedimentation (White et al., 1986; Blair and Bilodeau, 1988; Schlische and Olsen, 1990; Muto and Steel, 1997). We recognized in the Eastern Tyrrhenian Sea positive inversion structures superimposed on previous extensional basins. Even if several studies (Cooper and Williams, 1989; Coward, 1994; Buchanan and Peter, 1995; Tavarnelli, 1996; Sandiford, 1999; Tavarnelli and Peacock, 1999; Tavarnelli et al., 2001; Turner and Williams, 2004; De Paola et al., 2005; Henk and Nemčok, 2008) claim that the positive inversion structure involves the reversal of extensional fault movement during contractional tectonics, some examples from basin research show that positive inversion involves flexural arching of prior lows or sedimentary basins and is not dependent on fault slip for its development (Harding, 1985; Corfield et al., 1996). In fact, some theoretical and case studies demonstrate that the reverse-sense fault displacement of major faults does not appear in mild-inversion, until all the normal-sense displacement is lost beyond the null-point in moderate-to-strong-inversion (Cooper and Williams, 1989; Song, 1997; Turner and Williams, 2004; Jackson et al., 2013). Therefore, the changes of structural relief from previous lows (outlined by thick deposits) to highs (outlined by flexural arching or uplift) indicates the structural inversion in seismic lines, even if without reverse-reactivation of prethrusting normal faults (e.g. Tavarnelli, 1996).

The recognition of the syn-kinematic strata in the basin infill, and the analysis of the interplay between stratigraphic horizon and faulting enabled us to assign an age to fault activity in the Eastern Tyrrhenian Sea. Here we divided the fault structures into three groups according to their age.

\subsection{Lower Pleistocene structures}

Along the Campania margin the deposition of Unit A was mainly controlled by NW-trending graben and NE-SW transfer faults (Fig. 9). In the North there is a triangular basin (Northern Gaeta Bay), bounded by NNE-trending faults and NW-trending faults, with the apex located in the northern coast, and by an E-W transform fault (Milia et al., 2013). Unit A filled also two thick and large NW-SE trending graben: the Campania Plain and Campi-Flegrei-Naples Bay basins (Milia et al., 2013; Milia, 1999; Milia and Torrente, 1999, 2015b). Two thickness maxima $>1.9 \mathrm{~s} \mathrm{(twtt)}$ are present in the Salerno Bay and Cilento basins (Fig. 9). The Salerno Bay Basin, covering an area of approximately 365 $\mathrm{Km}^{2}$, is characterized by an array of NW-trending normal faults that forms graben structures (Fig. 5). These normal faults end abruptly toward northwest and southeast against NE-trending high-angle transfer faults (Figs. 5, 9). The Cilento Basin, located on the slope in the offshore of the Cilento Promontory, covers an area of approximately $345 \mathrm{Km}^{2}$ and is NW-SE elongated (Fig. 9). Furthermore, other NW-trending normal faults were active in the Campania Margin, offshore Capri Island 


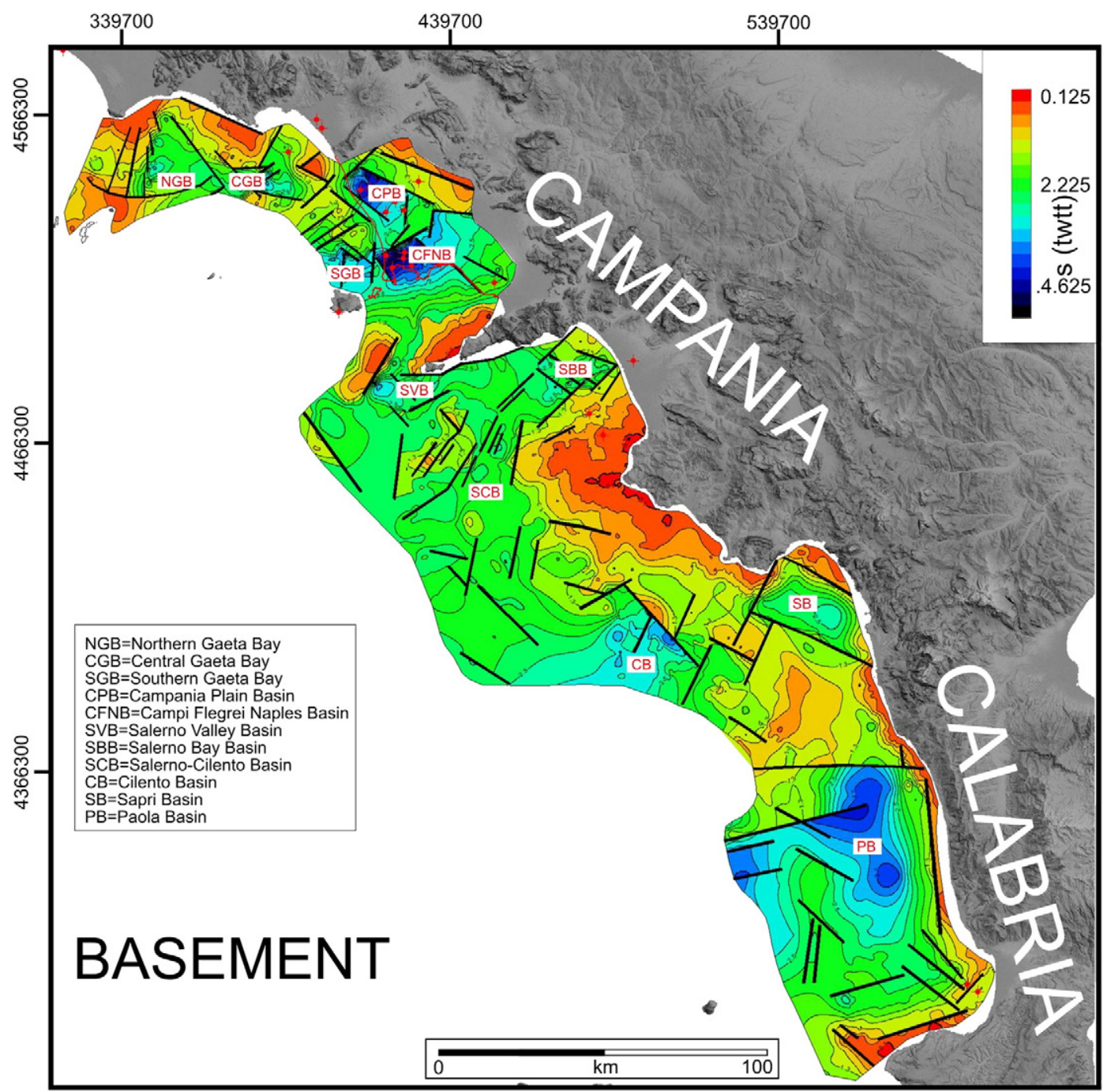

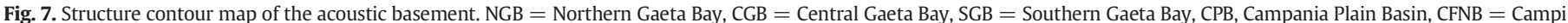

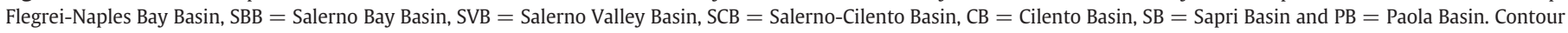
interval is $0.20 \mathrm{~s}$.

and in the Sorrento Peninsula, during the Lower Pleistocene (Milia and Torrente, 1997). A geological link between the Southern Campania Margin (Cilento offshore) and bathyal Marsili basin is presented by the CROP M6B seismic profile (Fig. 13b). The oldest structures correspond to normal faults (F16, F15, F14) bounding the Tyrrhenian bathyal zone. The multibeam map of the Tyrrhenian Sea (Marani et al., 2004) reveals that these structures trend NW-SE and correspond to the Sartori Lineament Auct. These boundary faults down throw the basement at a depth $>5 \mathrm{~s}$ (approximately $3800 \mathrm{~m}$ ) and are responsible for the crustal thinning linked to the formation of the bathyal region. The age of sediments that onlap the acoustic basement and these faults has been calibrated using the stratigraphy of the ODP Site 650 drilled in the Marsili basin, that is characterized, from older to younger, by $32 \mathrm{~m}$ of vesicular basalts overlain by a 602 m-thick succession of Pleistocene, where the oldest sediments are 2.0 Ma-old (biozone MPL6/NN18; Channell et al., 1990). Thus, these NW-SE faults (F16, F15, F14) date from the Lower Pleistocene.

Unlike the Campania Margin, in the Calabria Margin, the structures controlling the deposition of the Unit A (Fig. 9), are E-W trending synsedimentary faults (Milia et al., 2009) and pre-existing upper Miocene NNW-SSE trending normal faults (Milia and Torrente, 2014). Unit A is folded and presents in its upper part a syn-sedimentary wedge (Fig. 6). 3-D architecture of the folds and their relationships with the tectonically enhanced unconformities were reconstructed. The 3-D model of the 1.0 surface shows (Fig. 6b) folds with en échelon pattern corresponding to large antiforms and a main synform that deepens in the central part of the basin. The en échelon fold pattern is consistent with the occurrence of a NW-SE sinistral shear zone (Milia et al., 2009). In conclusion, the Calabria Margin recorded a change in the tectonic regime from extension to strike slip regime.

\subsection{Early Middle Pleistocene structures}

The isochron map of the Unit B shows several thickness maxima (Fig. 11). On the base of the stratal architecture, we distinguished two basin styles: (i) basins characterized by low to moderate symmetrical subsidence, whose sediments prograde from the coast toward the sea filling the depocenters (Northern Gaeta Bay Basin, Salerno Bay Basin, Paola Basin; (Fig. 5); (ii) half graben basins featuring asymmetrical high subsidence controlled by NE-SW normal faults (Figs. 3, 4). This second category includes the Campi Flegrei-Naples Bay basin featuring basal angular unconformity and basin architecture that documents a block faulting coeval to the deposition of Unit B. Because the Campi Flegrei-Naples Bay basin is underfilled by Unit B sediments, it is easily identified in the contour map of horizon 0.7 (Fig. 14), but it is not evident in the isochron map (Fig. 11). During this time, it started the formation of the Central Gaeta Bay and Campania Plain basins, Salerno Valley basin, Capri Basin, and Salerno-Cilento basin, with the deposition 


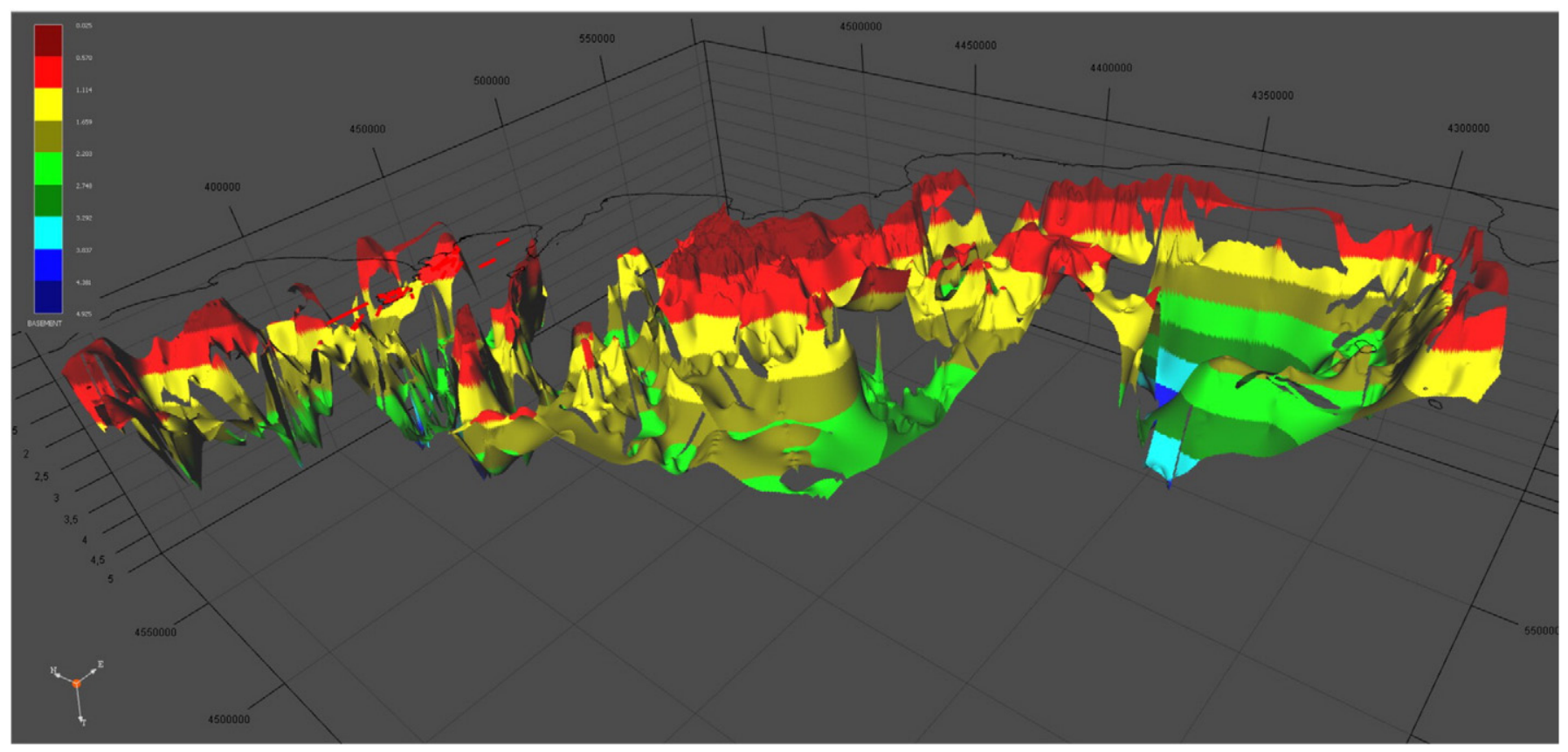

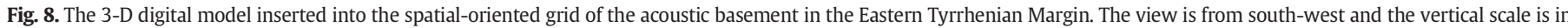
seconds.

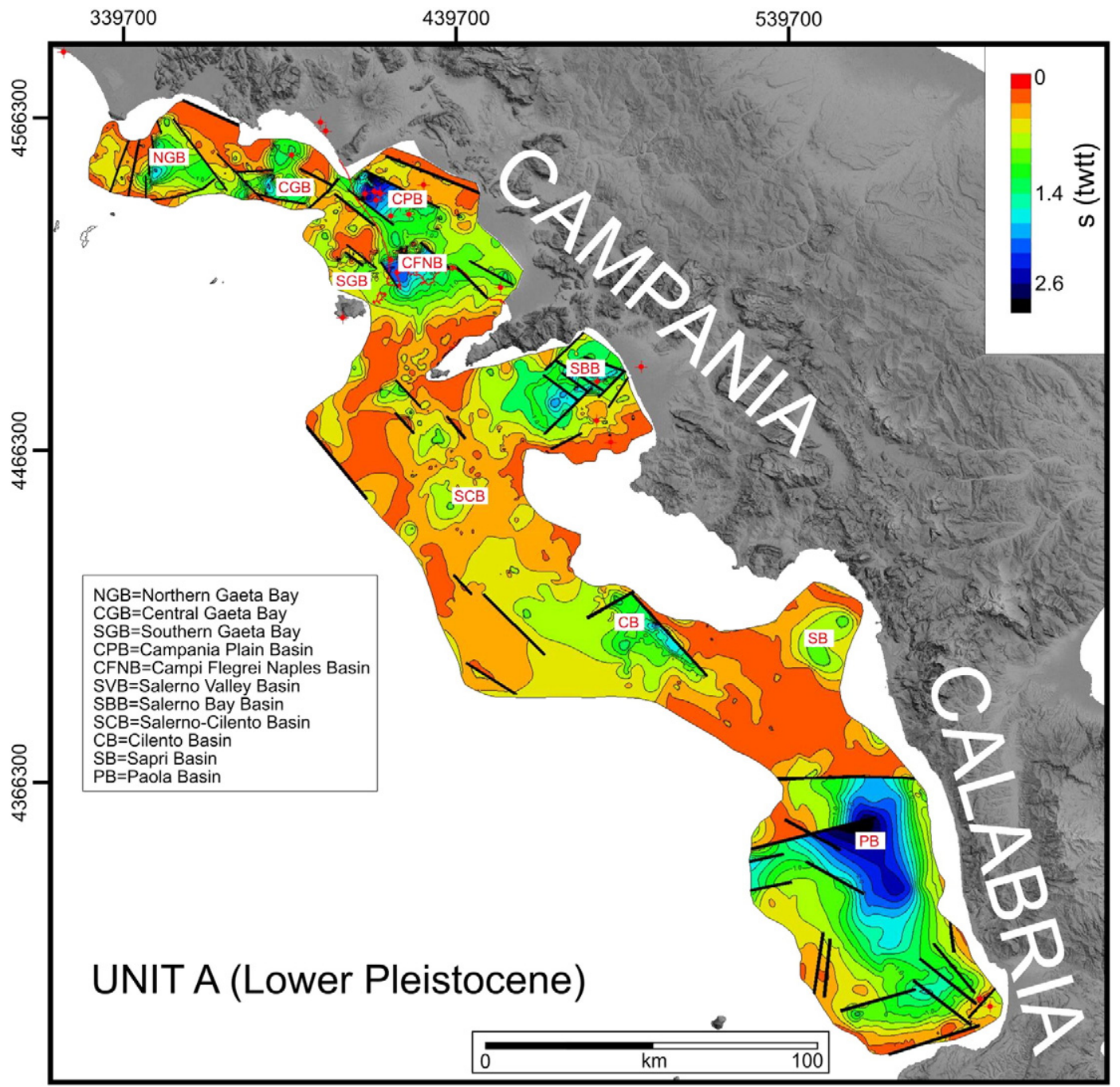

Fig. 9. Isochron map of Unit A in the Eastern Tyrrhenian margin. Contour interval is $0.20 \mathrm{~s}$. 


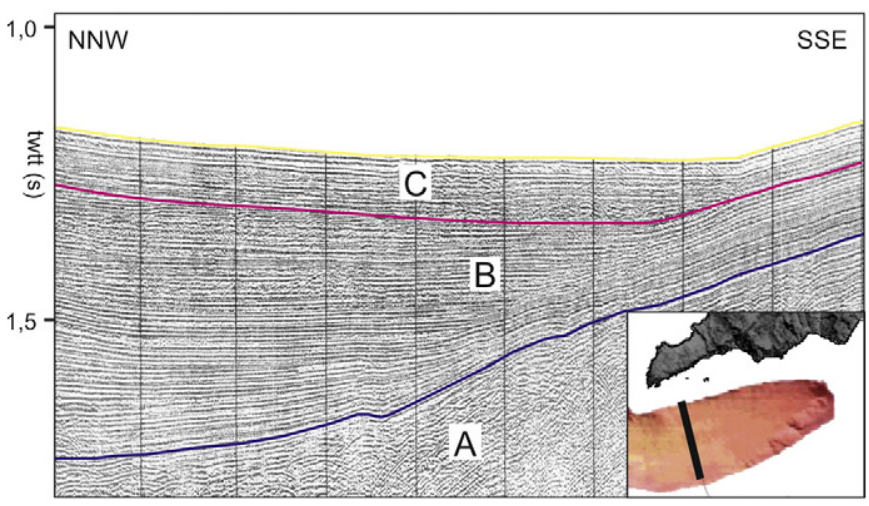

Fig. 10. Interpreted seismic section across the Salerno Valley basin. $A=$ Unit A, B = Unit B, $\mathrm{C}=$ Unit $\mathrm{C}$.

of their sediments as syn-kinematics wedges. In particular the CROP M36 seismic profile displays (Fig. 13): (i) asymmetrical fault blocks dipping toward NW and bounded by NE trending normal faults (BFF, F8, F9); (ii) two structural highs bounding the Salerno Valley and the Salerno-Cilento basins; (iii) a main angular unconformity between Lower and Middle Pleistocene deposits, marking the tilting of the fault blocks. It is worth noting that the activity of NE-trending faults during the deposition of the unit B was limited to the area between the Central Gaeta Bay Basin to the North and offshore Salerno bay to the South.
Prominent pop up and inversion structures were recognized off Naples Bay and in the Salerno Bay. Offshore Naples Bay, the interpretation of both multibeam bathymetry (Fig. 2) and CROP M30 seismic profile (Fig. 15) reveals a NW-SE, $40 \mathrm{~km}$-long and $5 \mathrm{~km}$-wide, pop-up structure (Sirene Seamount) bounded by high-angle reverse faults displacing Unit A. Its morphology displays an approximately $700 \mathrm{~m}$ high structural relief confined on both side by two symmetrical sedimentary basins [floored respectively, from NE to SW, at 1500 s (approximately $1000 \mathrm{~m}$ of water depth) and $1800 \mathrm{~s}$ (1350 m of water depth)], filled by Middle-Late Pleistocene deposits that cover unconformable the Lower Pleistocene deposits. According to the results of analogue models (Schellart and Nieuwland, 2003), we assume that the NW-SE Sirene Seamount pop up structure developed above a parallel basement strike slip fault. The NW-SE Sirene pop-up structure forms the western boundary of the Middle Pleistocene NE trending faults affecting the Campania margin. Because these NE-SW normal faults are absent in the contiguous Tyrrhenian bathyal zone, we interpret the Sirene structure as a transform fault developed at the boundary of the Middle Pleistocene SE-directed extension of the continental margin. In Salerno Bay the interpretation of seismic profile E-117 suggests that inversion structures formed after the sedimentation of the Unit A strata (Fig. 5). These strata, indeed, resulted folded, faulted and bounded at the top by an erosional surface covered by Unit B. Many folds and faults affect only the silicoclastic sedimentary succession (basinal Liguride units and Miocene clastic deposits) that covers the carbonatic basement, suggesting a Pleistocene reactivation of the oldest thrust surface. Therefore, during the

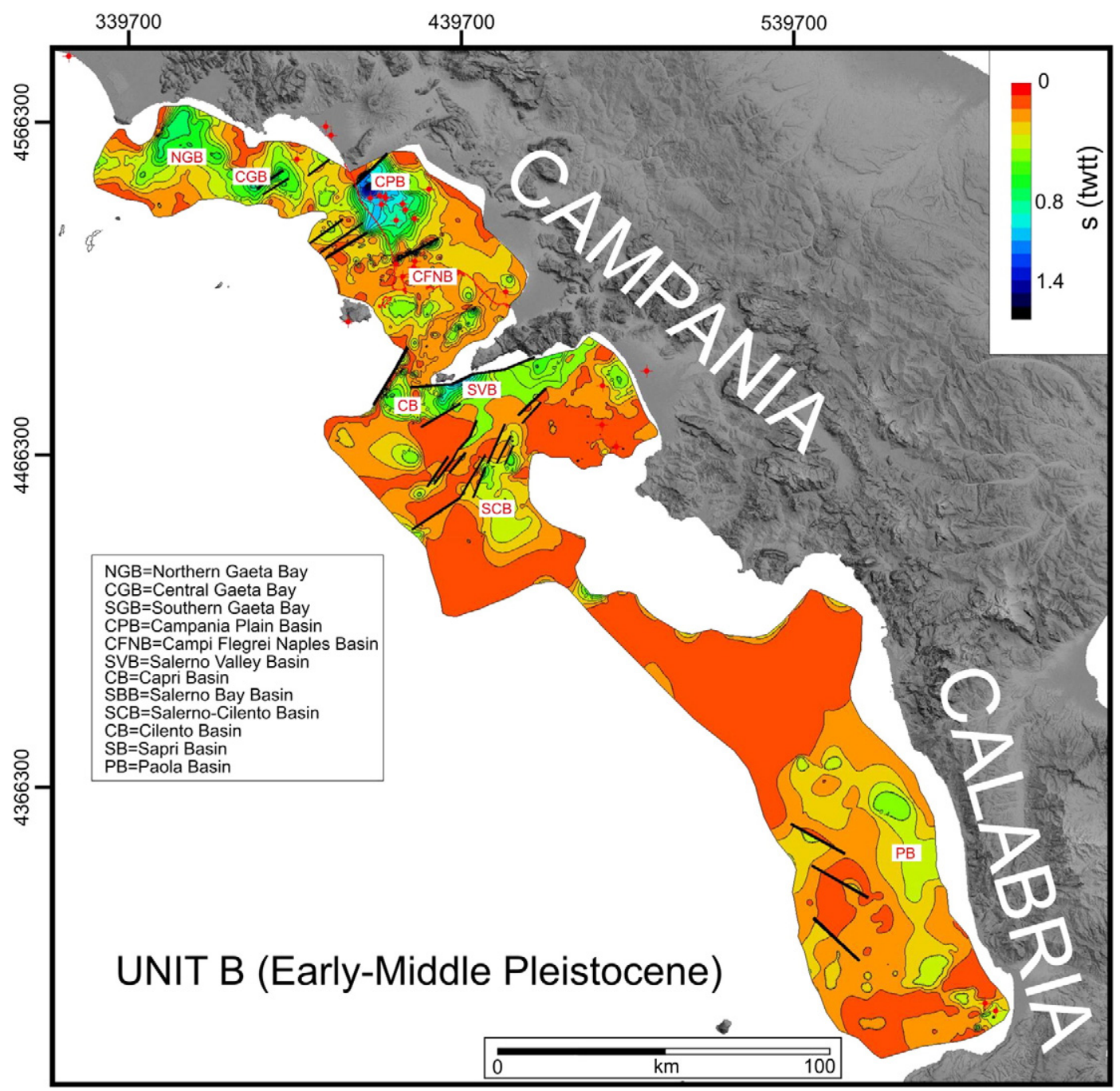

Fig. 11. Isochron map of Unit B in the Eastern Tyrrhenian margin. Contour interval is $0.20 \mathrm{~s}$. 


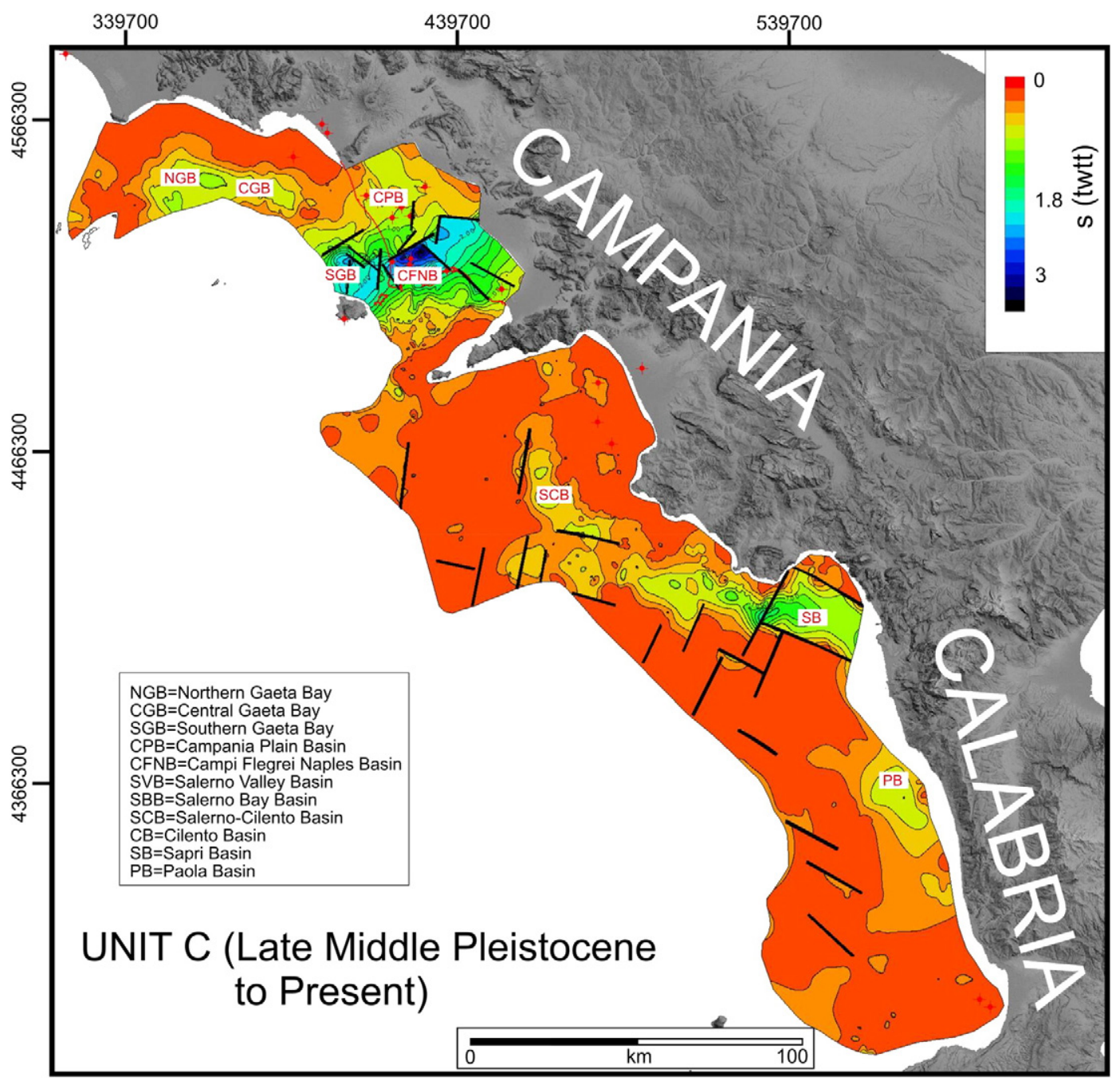

Fig. 12. Isochron map of Unit $C$ in the Eastern Tyrrhenian margin. Contour interval is $0.20 \mathrm{~s}$.

inversion tectonics, decoupling levels were activated in correspondence of the thrust fault and a disharmony between the stiff lower unit and the overlying thin-skinned covers unit was created. Similar structures have been documented in the Maracaibo basin (Roure et al., 1997).

It should be noted that the Salerno Bay basin changed from syn-rift to post-rift stage at lower/middle Pleistocene boundary, producing an angular unconformity. The undeformed prograding units (B and $\mathrm{C}$ Units) of the Salerno basin (seismic line E-204, Fig. 5) post-date the inversion tectonics and indicate a tectonic stability of the basin.

\subsection{Late Middle Pleistocene-present structures}

During this stage the extensional tectonics is only localized in the Campania Margin (Campania Plain, Southern Gaeta Bay and Sapri basins; Fig. 13). The stratigraphic signature of this rifting episode in the Campania Plain corresponds to a basal angular unconformity and an abrupt increase in water depth. A very rapid subsidence of the basin permitted the deposition of c. $500 \mathrm{~m}$ of prodelta mudstones that covered abruptly infra-littoral deposits (Cancello well, Milia and Torrente, 2015b). Voluminous volcanic activity and eastwards migration of fault-controlled asymmetrical subsidence from the Southern Gaeta Bay basin to the Campi Flegrei-Naples Bay basin occurred during the deposition of Unit C (Milia and Torrente, 2007, 2011; Torrente and Milia, 2013). The eastwards migration of extension is documented by a geological section (Fig. 16), displaying two stages of tectonic subsidence: (i) normal faults active between 0.4 and $0.1-0.15 \mathrm{Ma}$ in the Southern Gaeta Bay basin (Milia et al., 2013; Torrente and Milia, 2013); (ii) normal faults younger than $0.1 \mathrm{Ma}$ at Campi Flegrei-Naples Bay basin (Milia, 2000; Bellucci et al., 2006; Milia et al., 2006; Torrente et al., 2010; Milia and Torrente, 2011). In the Bay of Naples the lower part of Unit $C$ shows a rapid seawards progradation whereas its upper part is characterized by a thick volcanoclastic wedge deposited during a younger, post-0.1 Ma, tectonic subsidence stage (Figs. 4, 16) (Milia, 1999, 2000; Milia et al., 2006).

Offshore Cilento the entire stratigraphic succession is affected by folding and a wide deformation zone, approximately trending E-W, formed during Late Middle Pleistocene-Present (see map of Fig. 13). This deformation zone, going southwards corresponds to a restraining band and a releasing band of a strike-slip fault zone affecting the basement. In particular, folds and flexural arching, converging to a main vertical fault, visible in the CROP seismic profiles (Fig. 13a, central part of M36; Fig. 13b, northern part of M6B), can be linked to a positive structural inversion, while a negative flower structure occurs in the southern part of CROP seismic profile M36. Toward the South, in the Paola Basin, NW-SE dextral faults (see map of Fig. 13) were active and produced small pull apart basins (Milia et al., 2009). One of these features is imaged at the southern end of the CROP M36 seismic profile (Fig. 13c). It displays a flexural arching converging toward the main fault, 

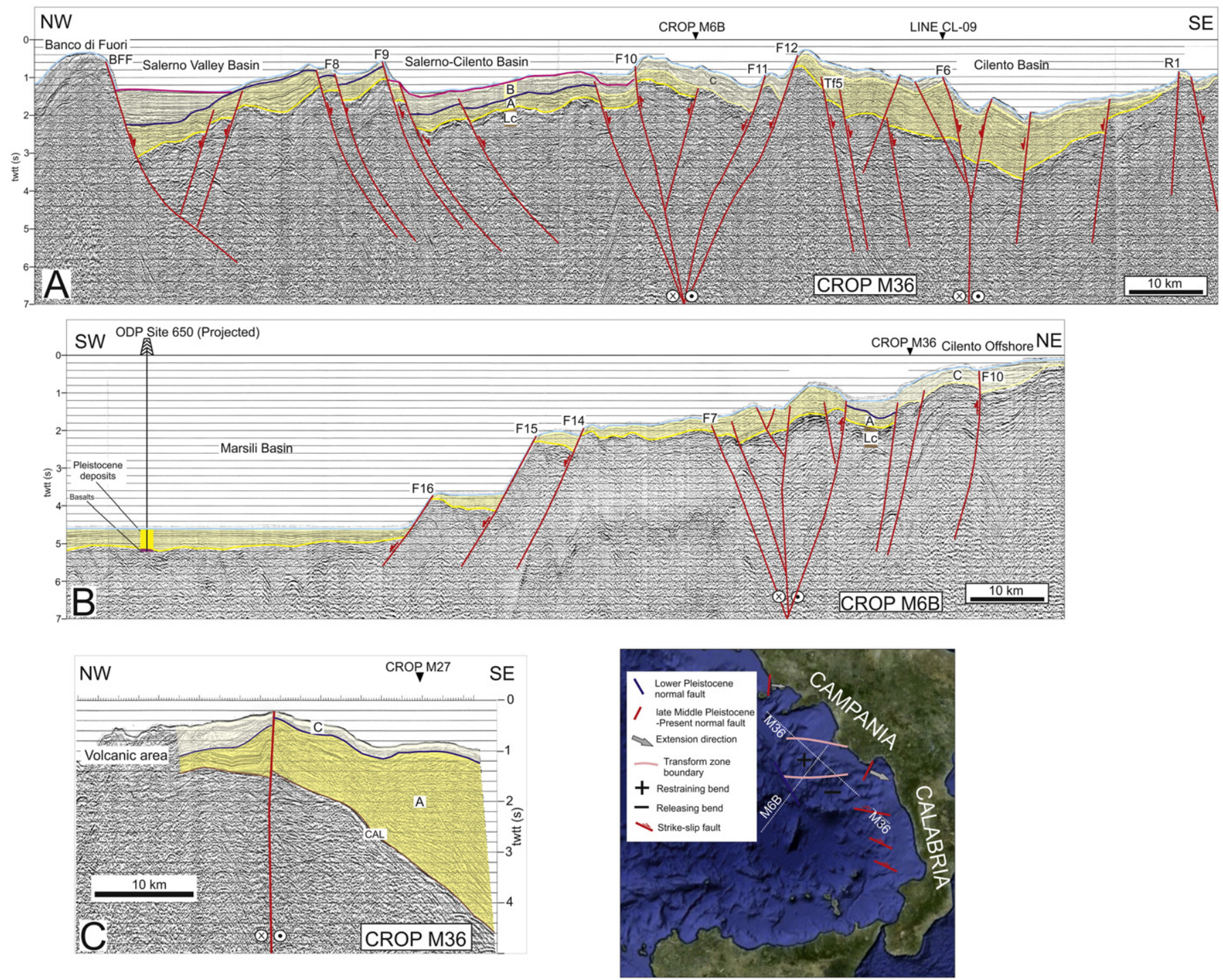

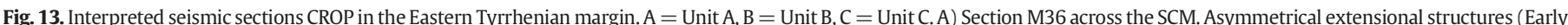

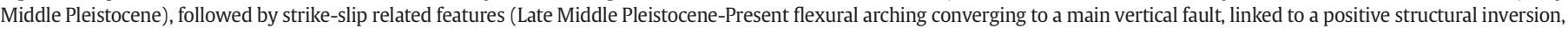

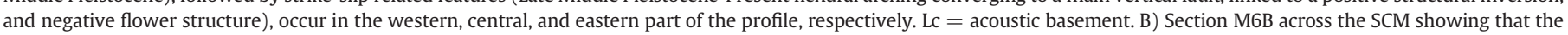

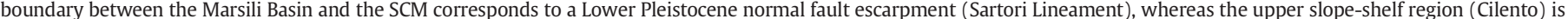

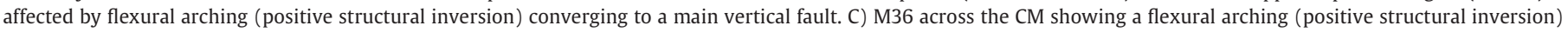
converging to a main vertical fault. $\mathrm{CAL}=$ Paleozoic crystalline rocks.

corresponding to an anticlinorium crest, and striking different seismic features North and South of this fault. This overall geometry confirms a lateral movement of the fault blocks.

\section{Discussion}

Interpreting the data discussed above together with the results of recent models of seismic tomography carried out in the ETM, allows to analyze the kinematic link existing between the lower and upper plate. In this way, we get a complete picture of the tectonic evolution of the ETM, lacking so far, despite the large amount of seismic and geological studies carried out in this area in the last fifteen years.

\subsection{Seismic tomography models of the subduction zone}

Knowledge of the mantle velocity structure beneath Apennine and Tyrrhenian Sea has been significantly improved in the last ten years using seismic tomography techniques. Despite intrinsic differences between local and regional tomography (i.e., model parameterization, ray tracing, approach to the inverse problem solution, and model reliability assessment), all recent models of the area are consistent on a large scale (e.g., Lucente et al., 1999; Bijwaard and Spakman, 2000; Piromallo and Morelli, 2003; Montuori et al., 2007; Chiarabba et al., 2008; Di Stefano et al., 2009; Koulakov et al., 2009; Neri et al., 2009; Giacomuzzi et al., 2012). They show an active subduction process of the Ionian oceanic slab, dipping $~ 70$ NW beneath the Calabrian arc and southern Tyrrhenian, down to $>600 \mathrm{~km}$. This process, associated with large positive velocities anomalies, is also confirmed by the distribution of the intermediate and deep seismicity. In contrast, strong negative velocity anomalies, observed beneath the central and southern Apennines down to 200-250 km depth, together with the absence of intermediate seismicity, indicate zones of unperturbed mantle, which has been interpreted as a gap in the subducted Adriatic slab.

The features discussed above are also visible in the recent regional seismic tomography model of Koulakov et al. (2009), available from open sources (http://www.ivan-art.com/science/REGIONAL/index. html). The model covers an area within $30^{\circ} \mathrm{N}, 55^{\circ} \mathrm{N} ; 5^{\circ} \mathrm{W}, 40^{\circ} \mathrm{E}$ and extends to a depth of about $700 \mathrm{~km}$. The initial data used by this model 


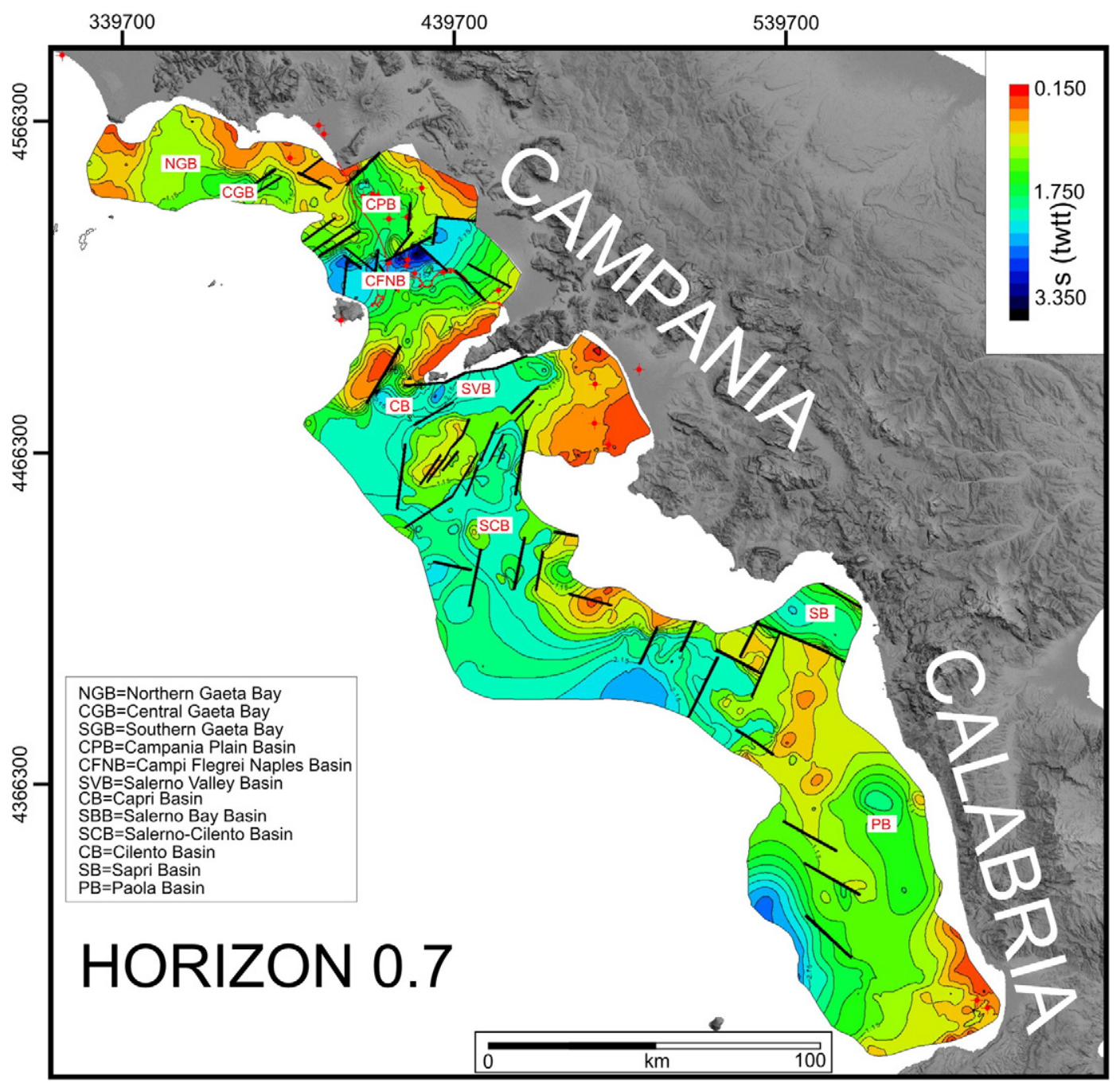

Fig. 14. Structure contour map of horizon 0.7. Contour interval is $0.20 \mathrm{~s}$.

included travel times of $P$ and $S$ body waves reported by the International Seismological Center (ISC, 2001). All seismic events in the time period from 1964 to 2001 were localized using the algorithm described in Koulakov and Sobolev (2006), which has as a major advantage the detection and rejection of the outliers present in the ISC catalogue. The crustal corrections were computed using EuCRUST-07, which provides estimates of depths and velocities of the upper/lower crust (Tesauro et al., 2008). We can observe from cross-section 1 (Fig. 17), drawn perpendicular to the strike of the belt, negative velocity anomalies (up to $-3.5 \%$ ) underlying the southern Apennines up to a depth of $\sim 250 \mathrm{~km}$. These anomalies indicate the flow of the asthenosphere between the lithosphere of the Adriatic plate, $100 \mathrm{~km}$ thick, and the detached part of the slab, sinking up to the bottom of the transition zone, which are in turn identified by positive velocity anomalies up to $\sim 2.5 \%$ (cross section 1, Fig. 17). Above the detached slab, beneath the Tyrrhenian Sea, there are strong negative anomalies (up to $-3-4 \%$ ), which have a thermal origin, being coincident with the location of Quaternary volcanos and areas of high heat flow (e.g., Zito et al., 2003). These observations, together with estimates of low subcrustal velocities (e.g., Di Stefano et al., 2009), shallow Moho depth (e.g., Panza, 1984), and S-wave attenuation (e.g., Marone et al., 2004) evidence significant crustal extension and asthenospheric upwelling.

The gap in the Adriatic slab tends to be progressively reduced toward the South and closes beneath the central part of the Calabrian Arc, where we can observe positive anomalies (up to 2.5\%), showing the active subduction of the Ionian slab (cross-section 2, Fig. 17). The latter tends to narrow in its uppermost part (at a depth $\sim 100 \mathrm{~km}$ ) up to $<100 \mathrm{~km}$, where the positive anomalies are reduced to $<1 \%$. Even if the fading of the positive anomalies at the same depths of the width reduction of the slab makes questionable its continuity, the occurrence of the earthquakes in this area confirms that the slab is undetached and subduction is still active. Southward the Calabrian Arc, beneath northeastern Sicily, there are negative anomalies up to $-2.5 \%$ down to $\sim 250 \mathrm{~km}$ (cross-section 3, Fig. 17), indicating the presence of a gap wide $\sim 100 \mathrm{~km}$, which induces asthenospheric upwelling between the Ionian and the African slab.

The origin of the slab break-off beneath the central and southern Apennines, which has likely caused magmas generation with transitional geochemical signatures, between arc type and ocean-island basalt (OIB) type, of the Quaternary Campania Province (Campi Flegrei, Vesuvius) and Vulture (e.g. Peccerillo, 2005; De Astis et al., 2006; Rosenbaum et al., 2008), is still matter of debate. Some authors have hypothesized that the Adriatic slab during its progressive rollback has been fragmented by tears, which caused flow of asthenospheric materials (e.g., Wortel and Spakman, 2000; Chiarabba et al., 2008; Di Stefano et al., 2009; Giacomuzzi et al., 2012). Using numerical models, Wortel and Spakman (2000) demonstrated that when a tear in the slab is generated, the decreased slab width may cause sudden acceleration of the retreat and an ultrafast opening of the back-arc regions. Indeed, in the segment of the plate boundary where a tear initiates, the slab pull is not transferred to the lithosphere at the surface, but the weight of the slab is at least partially supported by the still continuous part of the 


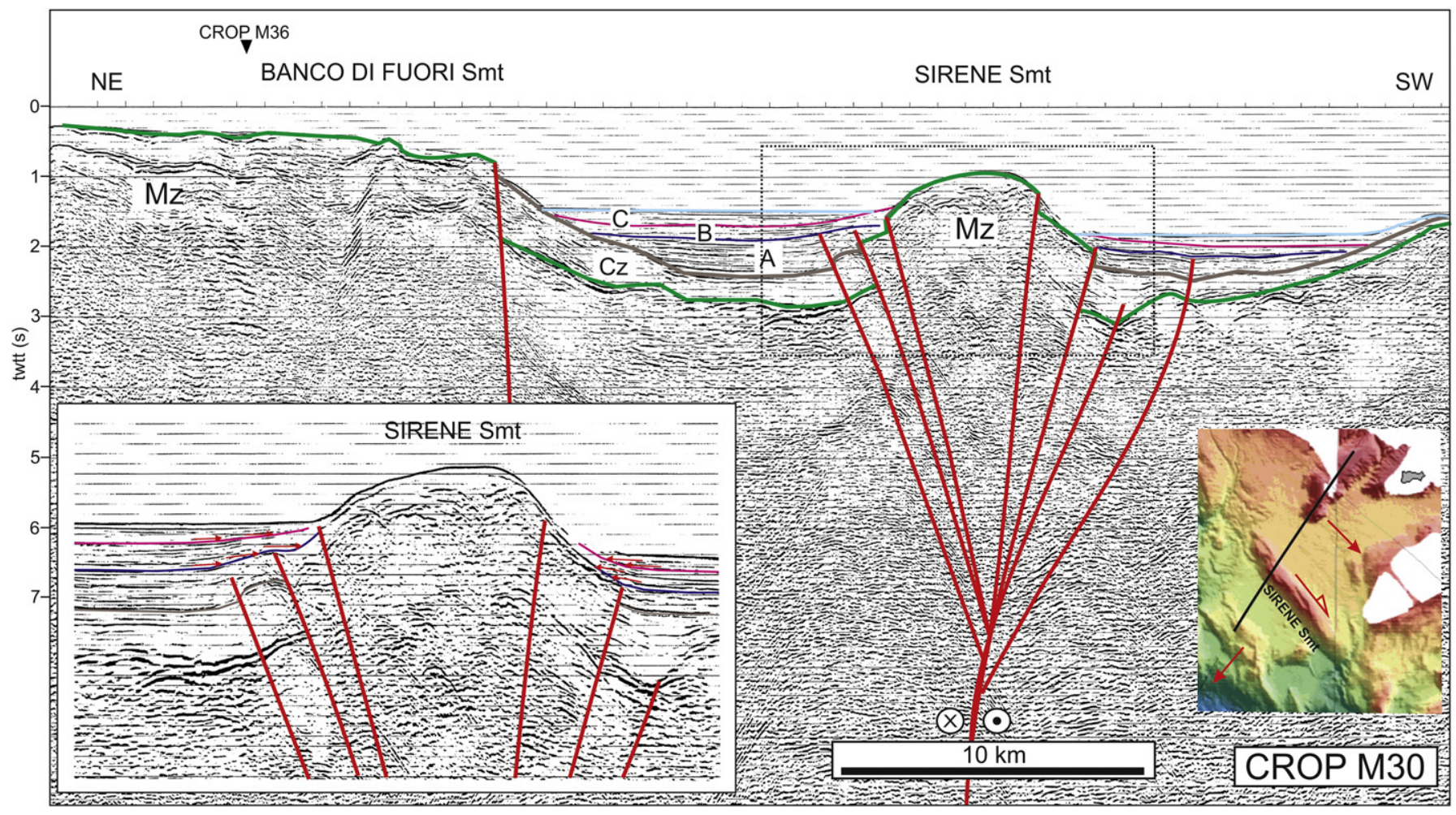

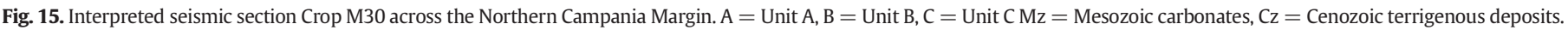
The red filled arrows in the map are extension directions. The lower inset displays the stratal terminations of Quaternary units.

slab. Stress concentration near the tip of the tear causes its lateral migration and velocity increase of the slab retreat (Wortel and Spakman, 2000). The development of slab tears is consequential to the formation of zone of weakness at the trench of the subduction zone, such as arrival of continental lithosphere after a period of oceanic lithosphere subduction (Wortel and Spakman, 2000). Heterogeneities inherited from Mesozoic tectonics along the passive margins of the Alpine Tethys ocean (European and African plates) and variations in the thickness and properties of the Adriatic and Ionian subducting lithosphere may have induced changes in the velocities of the slab retreat along the length of the subduction system and thus promoted the generation of slab tears (e.g., Di Stefano et al., 2009). According to other authors (e.g., Lucente and Speranza, 2001), the detachment process has not been induced by tear migration along the strike of the subduction zone, but is due to the entering of thick continental lithosphere in the trench and thus is spatially confined to the part of the subduction zone where the thicker lithosphere is present (i.e. the central-southern Apennines). However, the hypothesis of simultaneous slab detachment along a part of the plate boundary seems less likely, since the occurrence in a particular segment would activate the stress concentration mechanism and thus the tear migration (Wortel and Spakman, 2000). Furthermore, we should consider that 3D morphology of the slab beneath central and southern Apennines, constructed by projecting the positive seismic tomography anomalies down to the bottom of the transition zone, shows the presence of multiple fragmentations at various depths (Rosenbaum et al., 2008). According to other seismic tomography

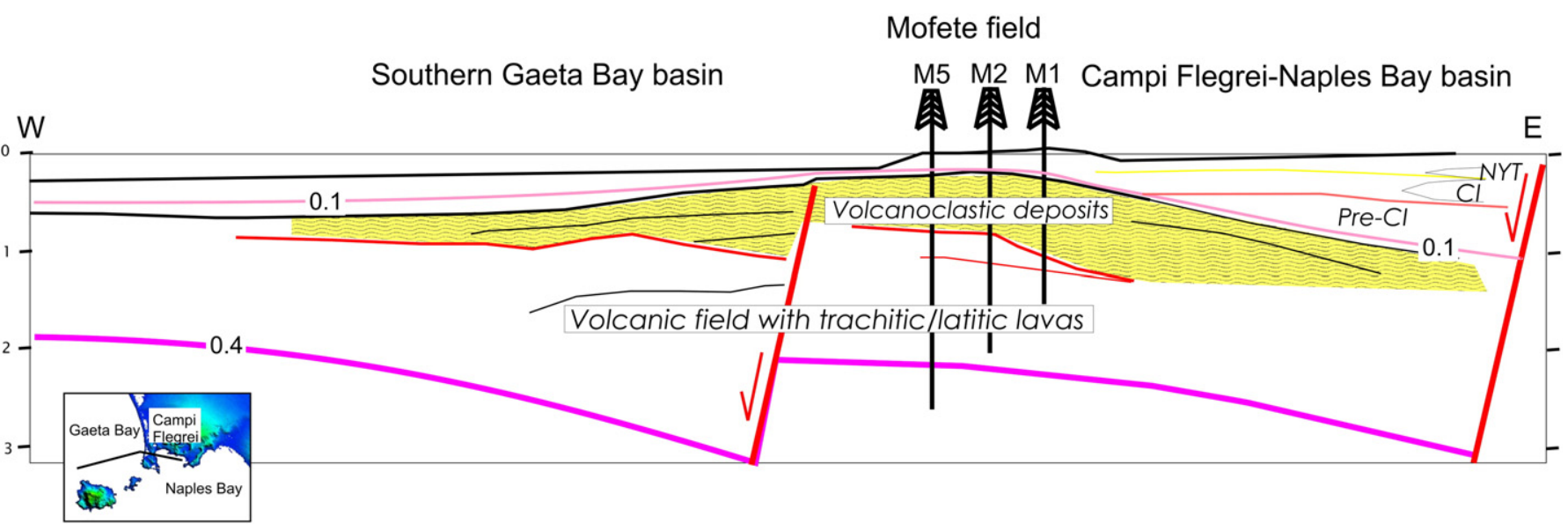

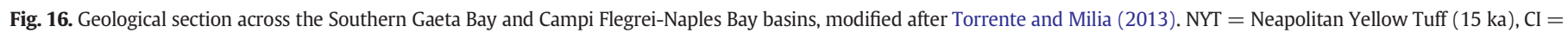
Campania Ignimbrite (39 ka), pre-CI $=$ pre-Campania Ignimbrite tuffs, $0.1=0.1 \mathrm{Ma}, 0.4=0.4 \mathrm{Ma}$. 


\section{$\mathrm{P}$, depth $100 \mathrm{~km}$}
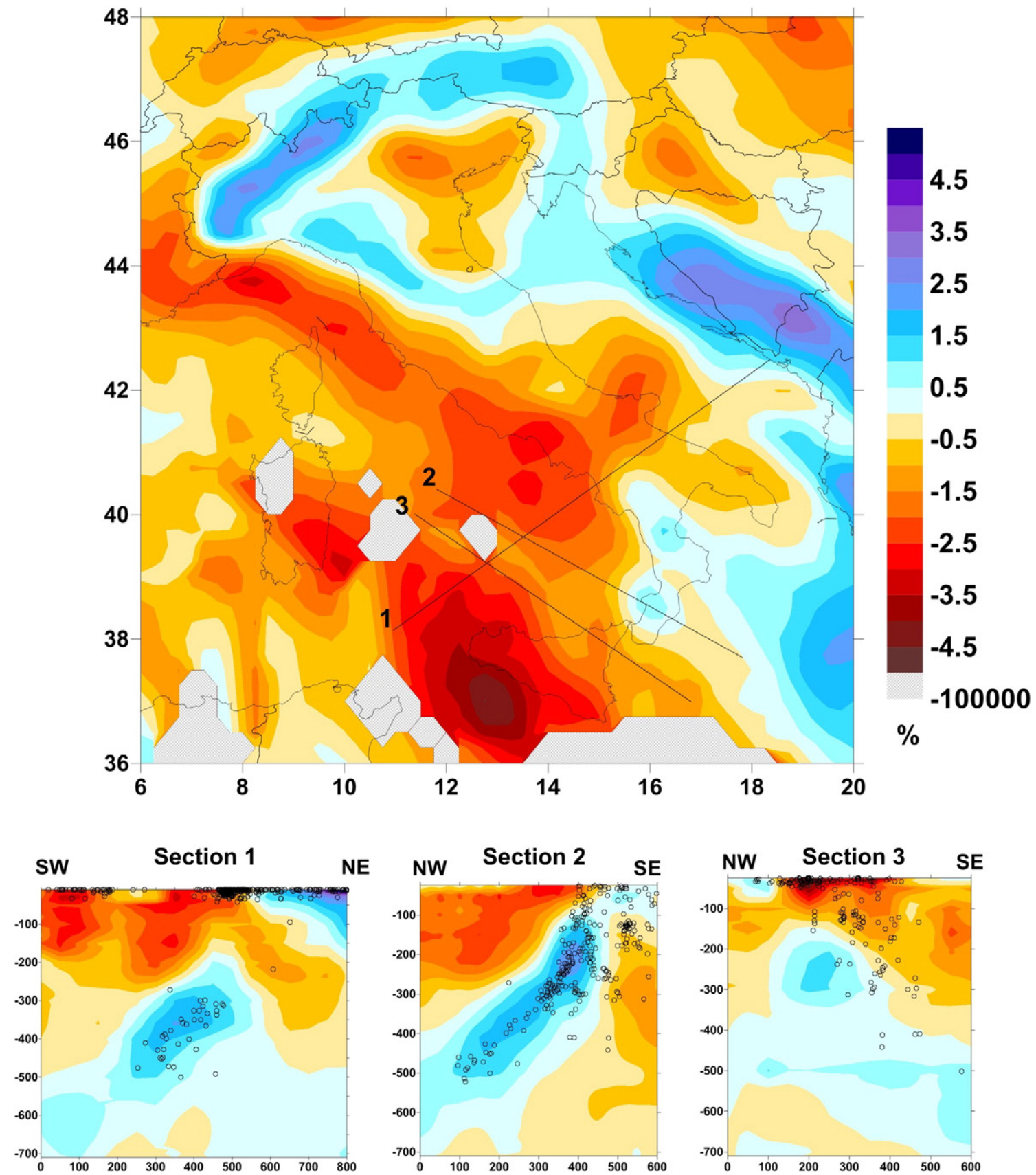

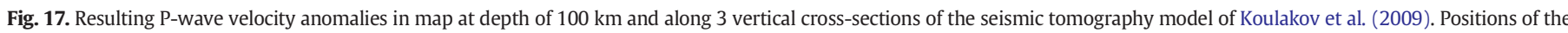

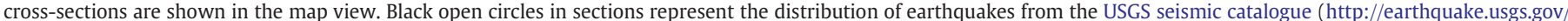
earthquakes/search/) at distances $<50 \mathrm{~km}$ from the cross-sections.

models, the Adriatic slab beneath the Neapolitan region is continuous, dividing the slab tear occurring beneath the Central Apennines from that present beneath the Southern Apennines (e.g., De Gori et al., 2001; Chiarabba et al., 2008; Giacomuzzi et al., 2012). The configuration of the seismic anomalies and the results of anisotropic studies (e.g., Civello and Margheriti, 2004) lead some authors to hypothesize a 3D mantle circulation (toroidal flow) causing asthenospheric flow toward the wedge around the sinking Ionian slab (e.g., Montuori et al., 2007; Faccenna et al., 2011). Therefore, the slab configuration in the Central Mediterranean is likely much more complex than that usually described in the numerical models.

\subsection{Upper plate Quaternary evolution}

The deformation phase of the ETM represents the last period of the Neogene Tyrrhenian Sea opening. Even if previous studies discussed the tectonic evolution of diverse sectors of the ETM, the tectonic history of the whole margin is still unclear. In this study, we describe all the phases of deformation of the ETM and contiguous Apennine belt. Quaternary extensional basins and transform faults developed along the ETM during several tectonic stages (each of which has a consistent kinematic evolution). The ETM structural pattern includes: poliphased extension and associated transform fault zones; changes in the direction 

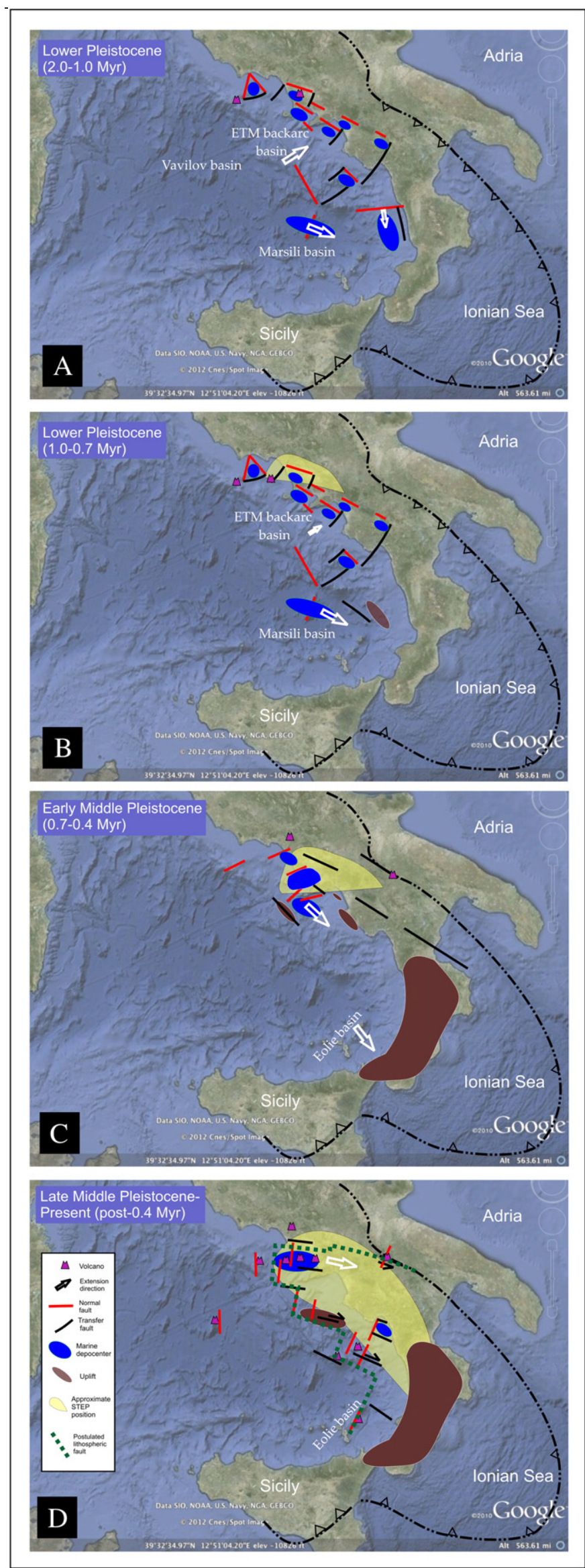

of extension; formation of thick sedimentary basins and uplift zones (Fig. 18).

During the Lower Pleistocene (2.0-1.0 Ma) extensional tectonics affected the entire ETM and the western flank of the Apennines, creating several basins (Fig. 18a): NW-SE trending normal fault formed in the NCM (e.g. Northern Gaeta Bay and Campania Plain basins), SCM (Salerno Bay, Cilento and Sele Plain basins), in Campania, and Basilicata (e.g. Diano and Auletta basins; Brancaccio et al., 1991; Barchi et al., 2007). NE-trending and E-W trending normal faults developed, in the Marsili and Paola basins, respectively. These three contemporaneous extension directions (NE-SW in the Campania margin, NW-SE in Marsili basin and $\mathrm{N}-\mathrm{S}$ in $\mathrm{CM}$ ) follow the double-saloon-door model by Martin (2006), characterized by a couple of oppositely propagating rifts and a coeval orthogonal third rift: the Campania margin and Marsili basin approximately match with the two arc-parallel rifts and the Paola basin with the rift orthogonal to the subduction zone. During this stage rapid counterclockwise rotations affected the hanging wall of the active thrust sheets along the outer front of the Apennines (Mattei et al., 2004).

In the late Lower Pleistocene (1.0-0.7 Ma; Fig. 18b) there was a change in the structural pattern: extensional faults continued their activity in the Campania Margin, Marsili basin, and western flank of the Apennines, while en échelon folds, linked to a NW-SE left-lateral transfer zone, formed in the CM. The activity of this transfer zone could be related to a higher speed of the Marsili basin opening, compared to that of the ETM.

In the Early Middle Pleistocene (0.7-0.4-Ma) an abrupt change of direction of extension (from NE-SW to NW-SE) in the ETM occurred (Fig. 18c). This change can be linked to the change of direction of the tectonic transport (from NE to SE) of the southern Apennines thrust belt (Patacca et al., 1990). The extensional basins related to this stage correspond to underfilled half grabens of the Campania margin (e.g. Campania Plain and Campi Flegrei-Naples Bay basins; Salerno Valley and Salerno-Cilento basins). During that time, NW-SE left lateral strike slip faults in the Apennines (Catalano et al., 2004; Schiattarella et al., 2005) and NW-SE transfer zones in the ETM were active. These transfer zones were affected by uplifts and inversion structures. We assume that the region of NW-SE strike-slip faulting of the upper plate has external boundaries corresponding to a couple of lithospheric tears: Vulture volcano fault and Sirene Seamount fault. Notably, at 0.7 Ma started the Quaternary uplift of Calabria (Westaway, 1993).

In the Late Middle Pleistocene to Present (post 0.4 Ma) extensional basins (Southern Gaeta Bay, Campana Plain-Campi Flegrei and Sapri basins) and transfer zone formed (Fig. 18d). Intense volcanism and eastwards migration of the extension was recorded in the NCM. NNEtrending normal faults developed in the ETM and Apennines (Vulture volcano, Schiattarella et al., 2005) and this extensional pattern is coherent with the migration of the Calabrian accretionary prism toward the E-SE. During this tectonic stage, a NW-SE transfer zone, featuring restraining and releasing bends, formed from the SCM to the $\mathrm{CM}$ at the southwest border of the ETM.

\subsection{Kinematic link between upper and lower plates}

Seismic tomography studies of Central Mediterranean revealed the existence of a gap in the structure of the subducted slab. According to Lucente et al. (2006) slab windows opened north (southern Apennines) and south (Sicily Channel) of the Ionian slab. Govers and Wortel (2005) instead reported two STEP faults at the northern and southern boundaries of the Ionian slab. The occurrence of a scissor-type detachment

Fig. 18. Kinematics of the Tyrrhenian backarc basin during Quaternary, modified after Milia et al. (2013) and Milia and Torrente (2015a, 2015b), including extension direction, volcanism, marine depocenters and uplift zones. Only the faults associated with each tectonic episode are shown. 


\section{Upper plate deformation}

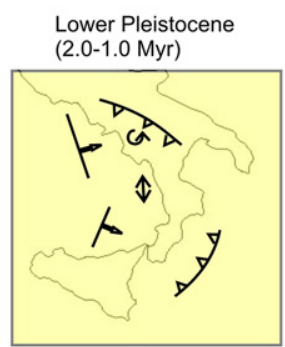

Lower Pleistocene (1.0-0.7 Myr)
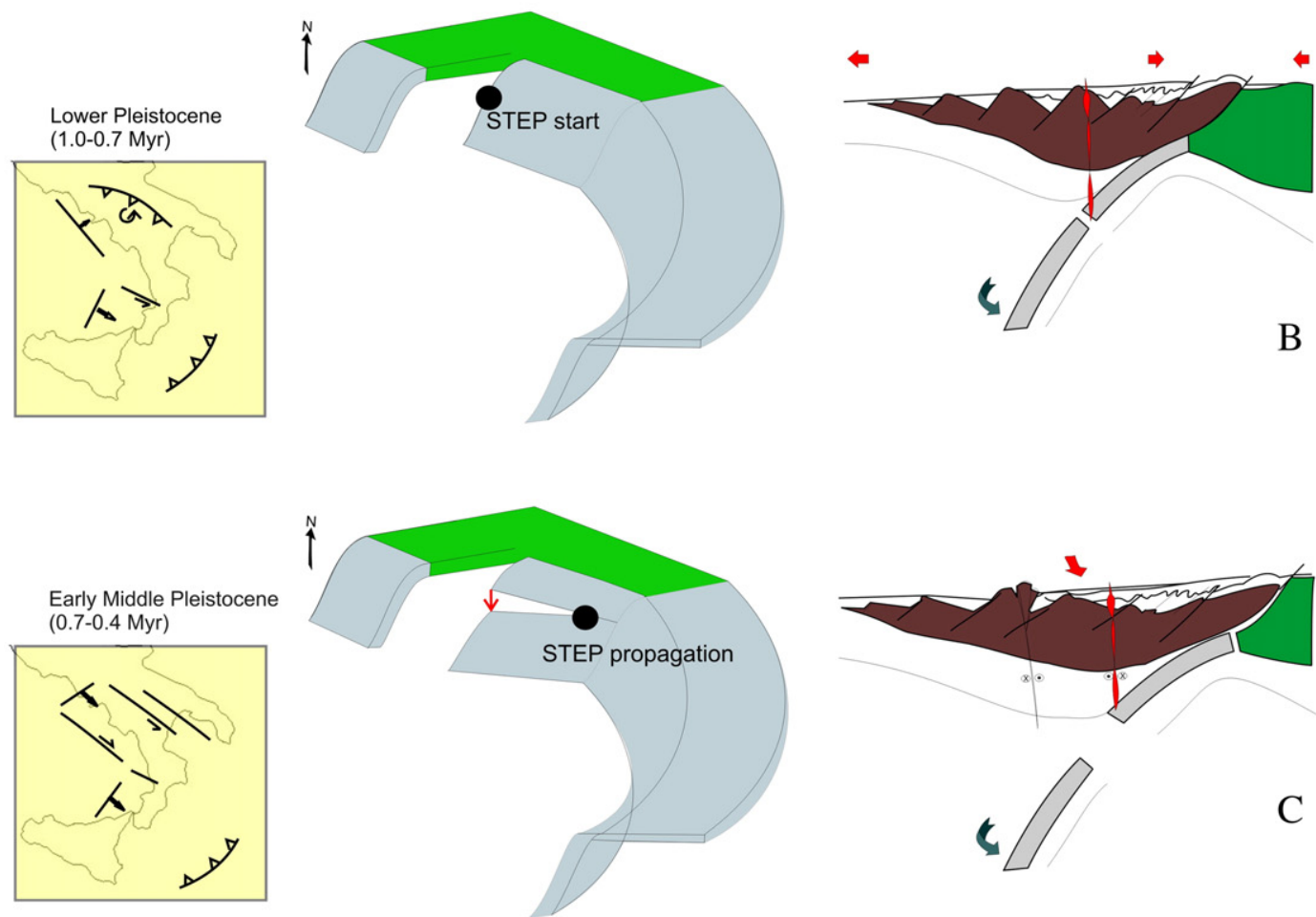

B
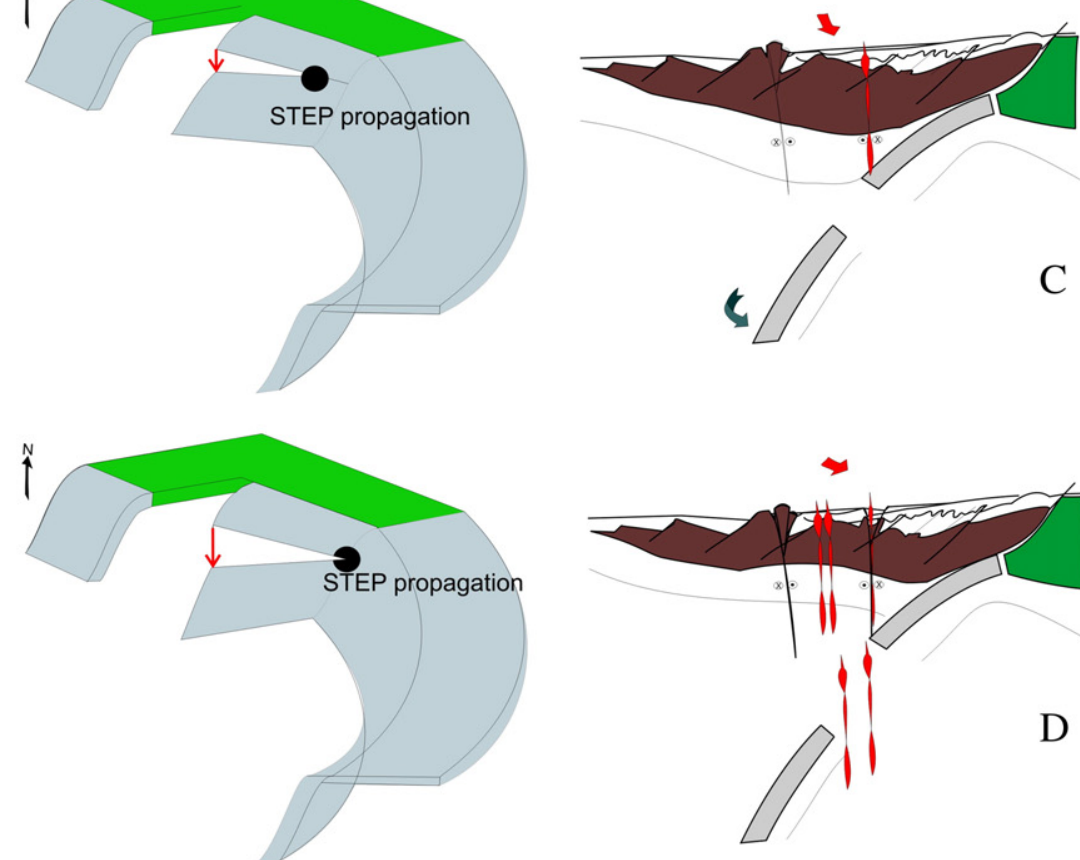

\section{$2 D$ lithospheric sections Upper/Lower plate deformation}

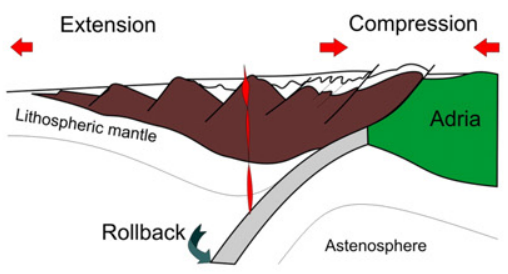

A
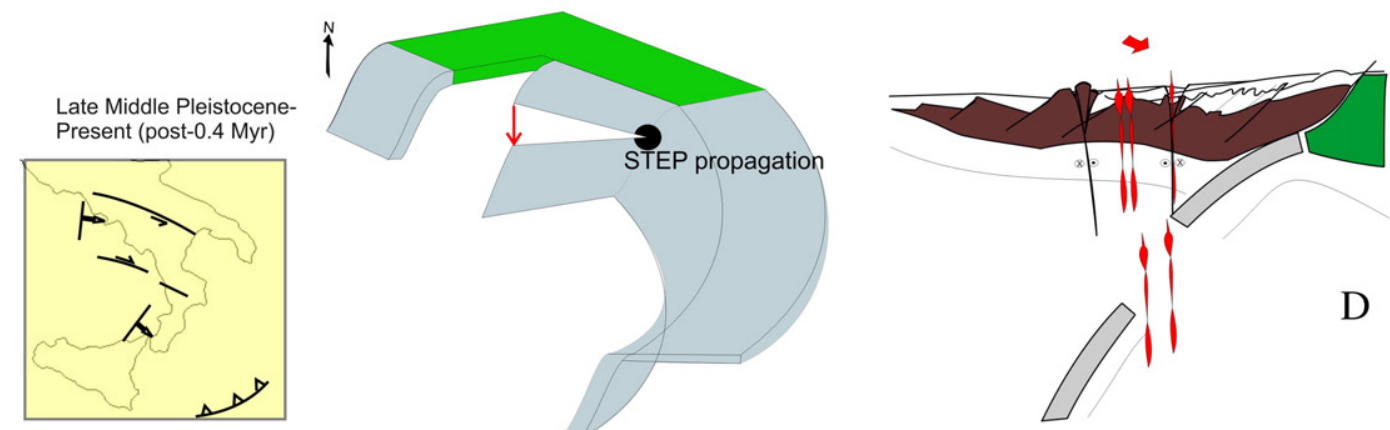

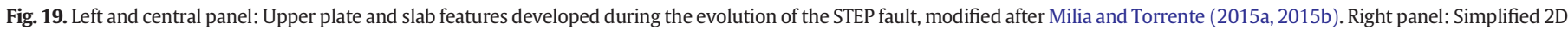
cross sections illustrating our interpretation of the evolution of the Adria slab.

(STEP) in the northern boundary of the Ionian slab is documented by an approximately $250 \mathrm{~km}$-long gap of the slab spanning from the Southern Apennines (Campania region) to the central part of Calabrian arc, where the slab is continuous.

A STEP fault has the potential to modify the surface topography on a kilometer scale, forming large sedimentary basins. Therefore, combining the space-time evolution of sedimentary basins of the ETM and the slab geometries, imaged from seismic tomography, we can understand the correlation between lower and upper plate deformation occurring in correspondence of the slab edge. To investigate the correlation between the evolution of sedimentary basins (timing and direction of extension) and occurrence of slab edge break-off and STEP 
propagation, we integrate multiple features of the hinge zone deformation of the upper plate (such us stratigraphic signature of tectonics, fault pattern, chronology of basin evolution), as well as the interpretations of seismic tomography data. We found a direct correspondence between lower plate rupture propagation and upper plate deformation, suggesting a genetic link between upper and lower plates.

We propose a possible geodynamic scenario characterized by a slab detachment linked to a STEP propagation (Figs. 18, 19).

a) During the Lower Pleistocene (2.0-1.0 Ma) the upper plate extension is directed perpendicular to the Apenninic trench (E-NE-directed) contemporaneously, in the southern part, the extension is directed perpendicular to the Ionian trench (SE-directed). The divergence in the direction of extension between these two regions implies the opening of an external basin between them (Paola Basin). The difference in the trench orientation can be due to the different velocity in the rollback of the continental and oceanic slab sectors.

b) Through the late Lower Pleistocene (1.0-0.7 Ma) the reduction in the extension value along the Campania Margin and the increase in the extension value of the Marsili basin, induce the formation of a transfer fault zone in the Calabria Margin. These features can be interpreted as the response in the upper plate of the STEP fault nucleation and rollback of the southern slab.

c) The Early Middle Pleistocene phase (0.7-0.4 Ma) was a period of plates re-organization that recorded: (i) abrupt change in the extension direction (from NE to SE), associated to the formation of rapidly evolving half graben localized in the Northern Campania Margin; (ii) end of the NE-directed thrust propagation in the Apennines and rapid uplift of Calabria. We should note that the deformation zone is localized in the ETM and bounded by two transfer zones toward the bathyal basins of the backarc and the external zone of the Apennines. The narrow belt of deformation is localized in correspondence of the northern boundary of the Ionian slab and can be interpreted as the response of the STEP fault propagation. The toroidal flow development around the northern edge of the Ionian and African slab (e.g., Montuori et al., 2007; Faccenna et al., 2011) would explain the upwelling of asthenospheric material beneath Calabria, and its rapid uplift (Gvirtzman and Nur, 1999).

d) The Late Middle Pleistocene-Present (post-0.4 Ma) period records a minor reorientation (E-SE) of the direction of extension in the ETM and the development of a restraining bend in the SCM. The NCM was characterized by large-volume volcanic eruptions and an increase of subsidence and extension associated to high crustal thinning (10 km at Campi Flegrei). This deformation stage indicates the enlargement of the gap effect of the continuum propagation of the STEP fault.

\section{Conclusions}

Based on seismic tomography studies, a general consensus exists on the gaps in the Adriatic slab, which induced the upwelling of hot asthenospheric material and generation of magmas with transitional geochemical signatures, between arc type and OIB type, of the Quaternary Campania Province (Campi Flegrei, Vesuvius) and Vulture volcanic complex (e.g. Peccerillo, 2005; De Astis et al., 2006; Rosenbaum et al., 2008). Several models of slab break-off have been proposed, which can be ascribed to two main categories, slab window and slab tear or STEP fault (e.g. Govers and Wortel, 2005; Rosenbaum et al., 2008). However, despite all the previous reconstructions of the complex geometry and boundaries of the Adriatic slab, age and mode of formation and evolution of the slab break-off remain unclear, without the interpretation of the kinematics of the upper plate. Indeed, the tectonic history of the deep and rapidly subsiding basins formed along the ETM allows to understand the mode of the interplay between lower and upper plate.
In this study, we combined the analysis of deep and shallow processes, mainly focusing on the relationship between the evolution of the lower plate (subduction slab) and upper plate (backarc sedimentary basins) and the resulting geodynamic implications. Our kinematic analysis reveals a WNW-trending deformation belt bounded by transfer faults, corresponding to the ETM, characterized by backarc opening with NEdirected extension in the Lower Pleistocene (2-0-0.7 Ma) followed by SE-directed extension in the Middle Pleistocene (post-0.7 Ma). This abrupt change of $\sim 90^{\circ}$ in the extension direction of the ETM during Quaternary is inconsistent with the features predicted by the current models of backarc opening. Therefore, we hypothesized the existence of a STEP fault currently bounding the northern margin of the Ionian plate. This STEP nucleated about $1 \mathrm{Ma}$ ago along the ETM, forming a gap in the Adriatic slab, which propagated for about $250 \mathrm{~km}$ southward reaching the central part of the Calabrian arc, where the slab is presently continuous. Notably, the deformation belt is bounded by lithospheric faults, which has favored recent volcanic activities, controlling magma rise from deep reservoirs to surface.

\section{Acknowledgements}

This study was funded by Università del Sannio (FRA 2015), Utrecht University, and the Netherlands Research Centre for Integrated Solid Earth Science (ISES-2014-UU-08, ISES-2016-UUU-19). We thank the IHS Inc. that provided the Kingdom software. We are grateful to E. Tavarnelli and G. Tari for the detailed review and highly stimulating comments. We acknowledge S. Cloetingh for his suggestions on an earlier version of the manuscript.

\section{References}

Amore, O.F., Bonardi, G., Ciampo, G., De Capoa, P., Perrone, V., Sgrosso, I., 1988. Relazioni tra "Flysch Interni" e domini appenninici: reinterpretazione delle formazioni di Pollica, S. Mauro e Albidona e il problema dell'evoluzione inframiocenica delle zone esterne Appenniniche. Memorie della Società Geologica Italiana 41, 285-297.

Anderson, H.J., Jackson, J., 1987. The deep seismicity of the Tyrrhenian Sea. Geophys. J. R. Astron. Soc. 91, 613-617.

Argnani, A., 2009. Evolution of the southern Tyrrhenian slab tear and active tectonics along the western edge of the Tyrrhenian subducted slab. In: Van Hinsbergen, D.J.J., Edwards, M.A., Govers, R. (Eds.), Collision and Collapse at the Africa-Arabia-Eurasia Subduction Zone. The Geological Society, London, Special Publications Vol. 311, pp. 193-212.

Argnani, A., Trincardi, F., 1988. Paola slope basin: evidence of regional contraction on the eastern Tyrrhenian margin. Memorie della Società Geologica Italiana 44, 93-105.

Barchi, M.R., Amato, A., Cippitelli, G., Merlini, S., Montone, P., 2007. Extensional tectonics and seismicity in the axial zone of the Southern Apennines. In: Mazzotti, A., Patacca, E., Scandone, P. (Eds.), CROP-04, Ital. J. Geosci. (Boll. Soc. Geol. It.), pp. 47-56.

Bartole, R., Savelli, D., Tramontana, M., Wezel, F.C., 1984. Structural and sedimentary features in the Tyrrhenian margin off Campania, southern Italy. Mar. Geol. 55, 163-180.

Bellucci, F., Milia, A., Rolandi, G., Torrente, M.M., 2006. Structural control on the Upper Pleistocene ignimbrite eruptions in the Neapolitan area (Italy): volcanotectonic faults versus caldera faults. In: De Vivo, B. (Ed.), Volcanism in the Campania Plain: Vesuvius, Campi Flegrei and Ignimbrites Vol. 9. Springer, Dev. Volcanol., pp. 163-180.

Bigi, S., Conti, A., Casero, P., Ruggiero, L., Recanati, R., Lipparini, L., 2013. Geological model of the central Periadriatic basin (Apennines, Italy). Mar. Pet. Geol. 42, 107-121.

Bijwaard, H., Spakman, W., 2000. Non-linear global P-wave tomography by iterated linearized inversion. Geophys. J. Int. 141, 71-82.

Blair, J.C., Bilodeau, W.L., 1988. Development of tectonic cyclotems in rift pull-apart and foreland basins: sedimentary response to episodic tectonism. Geology 16, 517-520.

Bodnar, R.J., Cannatelli, C., De Vivo, B., Lima, A., Belkin, H.E., Milia, A., 2007. Quantitative model for magma degassing and round deformation (bradyseism) at Campi Flegrei, Italy: implications for future eruptions. Geology 35 (9), 791-794. http://dx.doi.org/ 10.1130/G23653A.1.

Bonardi, G., Amore, F.O., Ciampo, G., De Capoa, P., Miconnet, P., Perrone, V., 1988. Il complesso liguride Auct.: stato delle conoscenze e problemi aperti sulla sua evoluzione pre-appenninica ed i suoi rapporti con l'Arco calabro. Memorie della Società Geologica Italiana 41, 17-36.

Bonardi, G., Ciarcia, S., Di Nocera, S., Matano, F., Sgrosso, I., Torre, M., 2009. Carta delle principali unità cinematiche dell'Appennino meridionale. Nota illustrativa. Ital. J. Geosci. (Boll. Soc. Geol. It.) 128, 47-60.

Brancaccio, L., Cinque, A., Romano, P., Russo, F., Santangelo, N., Santo, A., 1991. Geomorphology and neotectonic evolution of a sector of the Tyrrhenian flank of the southern Apennines (Region of Naples, Italy). Zeit. Geomorphol. 82, 47-58.

Brocchini, D., Principe, C., Castratori, D., Laurenzi, M.A., Gorla, L., 2001. Quaternary evolution of the southern sector of the Campanian Plain and early Somma-Vesuvius activity: insights from Trecase 1 well. Mineral. Petrol. 73, 67-91. 
Brosolo, L., Mascle, J., Loubrieu, B., 2012. Carte morpho-bathymétrique de la Méditerranée à l'echelle $1 / 4000$ 000. Commission de la Carte Géologique du Monde.

Buchanan, J.G., Peter, G.B. (Eds.), 1995. Basin inversionGeol. Soc. Lond., Spec. Publ. 88.

Burrus, J., 1984. Contribution to the geodynamic synthesis of the Provençal Basin (NorthWestern Mediterranean). Mar. Geol. 55, 247-269.

Carlino, S., Somma, R., Troise, C., De Natale, G., 2012. The geothermal exploration of Campanian volcanoes: historical review and future development. Renew. Sust. Energ. Rev. $16,1004-1030$.

Carminati, E., Wortel, M.J.R., Spakman, W., Sabatini, R., 1998. The role of slab detachment processes in the opening of the western-central Mediterranean basins: some geological and geophysical evidence. Earth Planet. Sci. Lett. 160, 651-665.

Casciello, E., Cesarano, M., Conforti, A., D'Argenio, B., Marsella, E., Pappone, G., Sacchi, M., 2004. Extensional detachment geometries on the TYRRHENIAN Margin (the Salerno District). In: Pasquarè, G., Venturini, C., Groppelli, G. (Eds.), Mapping Geology in Italy. APAT, Rome, pp. 29-34.

Catalano, R., Doglioni, C., Merlini, S., 2001. On the Mesozoic Ionian Basin. Geophys. J. Int. $14,1-24$.

Catalano, S., Monaco, C., Tortorici, L., 2004. Neogene-Quaternary tectonic evolution of the southern Apennines. Tectonics 23, TC2003. http://dx.doi.org/10.1029/2003TC001512.

Catalano, S., Monaco, C., Tortorici, L., Tansi, C., 1993. Pleistocene strike-slip tectonics in the Lucanian Apennine (southern Italy). Tectonics 12, 656-665.

Cavinato, G.P., De Celles, P.G., 1999. Extensional basins in the tectonically bimodal central Apennines fold-thrust belt, Italy: response to corner flow above a subducting slab in retrograde motion. Geology 27, 955-958.

Cavuoto, G., Martelli, L., Nardi, G., Valente, A., 2004. Depositional systems and architecture of Oligo-Miocene Turbidite successions in Cilento (Southern Apennines). GeoActa 3, 129-147.

Channell, J.E.T., Rio, D., Sprovieri, R., Glacon, G., 1990. Biomagnetostratigraphic correlations from Leg 107 in the Tyrrhenian Sea. In: Kastens, K.A., Mascle, J., et al. (Eds.), Proceedings of the Ocean Drilling Program, Scientific Results. 107, pp. 669-682.

Cherchi, A., Montadert, L., 1982. Oligo-Miocene rift of Sardinia and the early history of the Western Mediterranean Basin. Nature 298, 736-739.

Chiarabba, C., De Gori, P., Speranza, F., 2008. The southern Tyrrhenian subduction zone: deep geometry, magmatism and Plio-Pleistocene evolution. Earth Planet. Sci. Lett. 268, 408-423. http://dx.doi.org/10.1016/j.epsl.2008.01.036.

Cimini, G., De Gori, P., 2001. Nonlinear P-wave tomography of subducted lithosphere beneath central-southern Apennines (Italy). Geophys. Res. Lett. 28, 4387-4390.

Cinque, A., Guida, F., Russo, F., Santangelo, N., 1988. Dati cronologici e stratigrafici su alcuni depositi continentali della Piana del Sele (Campania): i "Conglomerati di Eboli". Geografia Fisica e Dinamica Quaternaria 11, 39-44.

Cinque, A., Patacca, E., Scandone, P., Tozzi, M., 1993. Quaternary kinematic evolution of the southern Apennines: relationships between surface geological features and deep lithospheric structures. Ann. Geofis. 36, 249-259.

Civello, S., Margheriti, L., 2004. Toroidal mantle flow around the Calabria slab (Italy) from SKS splitting. Geophys. Res. Lett. 31, L10601. http://dx.doi.org/10.1029/ 2004 GL019607.

Cloetingh, S., Burov, E., Matenco, L., Beekman, F., Roure, F., Ziegler, P.A., 2013. The Moho in extensional tectonic settings: insights from thermo-mechanical models. Tectonophysics 60, 558-604.

Cloetingh, S., Ziegler, P.A., Beekman, F., Burov, E., Garcia-Castellanos, D., Matenco, L., 2015. Tectonic models for the evolution of sedimentary basins. In: Schubert, G. (Ed.), Treatise on Geophysics, Second Edition Volume 6. Crustal and Lithosphere Dynamics, Elsevier, pp. 513-592.

Cohen, K.M., Gibbard, P.L., 2010. Global Chronostratigraphical Correlation Table for the Last 2.7 Million Years, v. 2010. http://www.quaternary.stratigraphy.org.uk/charts.

Cooper, M.A., Williams, G.D. (Eds.), 1989. Inversion tectonicsGeol. Soc. Lond., Spec. Publ. 44.

Corfield, S.M., Gawthorpe, R.L., Gage, M., Fraser, A.J., Besly, B.M., 1996. Inversion tectonics of the Variscan foreland of the British Isles. J. Geol. Soc. Lond. 153, 17-32.

Coward, M.P., 1994. Inversion tectonics. In: Hancock, P.L. (Ed.), Continental Deformation. Pergamon Press, Tarrytown, NY, pp. 289-304.

D'Ambrogi, C., Pantaloni, M., Borraccini, F., De Donatis, M., 2004. A 3D geological model of the Fossombrone area (Northern Apennines). Mapping geology in Italy. APAT Dipartimento Difesa del Suolo-Servizio Geologico d'Italia, Rome, pp. 193-198.

De Astis, G., Kempton, P.D., Peccerillo, A., 2006. Trace element and isotopic variations from Mt. Vulture to Campanian volcanoes: Constraints for slab detachment and mantle inflow beneath southern Italy. Contrib. Mineral. Petrol. 151, 331-351. http://dx.doi.org/ 10.1007/s00410-006-0062-y.

De Donatis, M., 2001. Three-dimensional visualization of the Neogene structures of an external sector of the northern Apennines, Italy. Am. Ass. Petr. Geol. Bull. 85, 419-431.

De Gori, P., Cimini, G.B., Chiarabba, C., De Natale, G., Troise, C., Deschamps, A., 2001. Teleseismic tomography of the Campanian volcanic area and surrounding Apenninic belt. J. Volcanol. Geotherm. Res. 109, 55-75.

De Paola, N., Holdsworth, R.E., McCaffrey, K.J., Barchi, M.R., 2005. Partitioned transtension: an alternative to basin inversion models. J. Struct. Geol. 27 (4), 607-625.

De Vivo, B., Belkin, H.E., Barbieri, M., Chelini, W., Lattanzi, P., Lima, A., Tolomeo, L., 1989. The Campi Flegrei (Italy) geothermal system: a fluid inclusion study of the Mofete and San Vito fields. J. Volcanol. Geotherm. Res. 36, 303-326.

De Voogd, B., Truffert, C., Chamot-Rooke, N., Huchon, P., Lallemant, S., Le Pichon, X., 1992. Two-ship deep seismic sounding in the basins of the eastern Mediterranean Sea (Pasiphae cruise). Geophys. J. Int. 109, 536-552. http://dx.doi.org/10.1111/j.1365246X.1992.tb00116.x.

Della Vedova, B., Bellini, S., Pellis, G., Squarci, P., 2001. Deep temperatures and surface heat flow distribution. In: Vai, G.B., Martini, I.P. (Eds.), Anatomy of an Orogen: The Apennines and Adjacent Mediterranean Basin. Kluwer, Dordrecht, pp. 65-67.
Dewey, J.F., Helman, M.L., Turco, E., Hutton, D.H.W., Knott, S.D., 1989. Kinematics of the western Mediterranean. In: Coward, M.P., Dietrich, D., Park, R.G. (Eds.), Alpine Tectonics 45. Geol. Soc. Lond. Spec. Pub., pp. 225-283.

Dhont, D., Luxey, P., Chorowicz, J., 2005. 3-D modeling of geologic maps from surface data. Am. Ass. Petr. Geol. Bull. 89, 1465-1474.

Di Stefano, R., Kissling, E., Chiarabba, C., Amato, A., Giardini, D., 2009. Shallow subduction beneath Italy: three-dimensional images of the Adriatic-European-Tyrrhenian lithosphere system based on high-quality P wave arrival times. J. Geophys. Res. 114 B05305. http://dx.doi.org/10.1029/2008JB005641.

Doglioni, C., 1991. A proposal for the kinematic modelling of W-dipping subductions possible applications to the Tyrrhenian-Apennines system. Terra Nova 3, 423-434.

Fabbri, A., Gallignani, P., Zitellini, N., 1981. Geologic evolution of the peri-Tyrrhenian sedimentary basins. In: Wezel, F.-C. (Ed.), Sedimentary Basins of Mediterranean Margins: Proceedings/C.N.R. International Conference Held at Urbino University, pp. 101-126.

Faccenna, C., Davy, P., Brun, J.P., Funiciello, R., Giardin, D., Mattei, M., Nalpas, T., 1996. The dynamics of back-arc extension: an experimental approach to the opening of the Tyrrhenian Sea. Geophys. J. Int. 126, 781-795.

Faccenna, C., Funiciello, F., Civetta, L., D'Antonio, M., Piromallo, C., 2007. Slab disruption, mantle circulation, and the opening of the Tyrrhenian basins. Geol. Soc. Am. Spec. Pap. 418, 153-169.

Faccenna, C., Molin, P., Orecchio, B., Olivetti, V., Bellier, O., Funiciello, F., Minelli, L., Piromallo, C., Billi, A., 2011. Topography of the Calabria subduction zone (southern Italy): clues for the origin of Mt. Etna. Tectonics 30, TC1003. http://dx.doi.org/10. 1029/2010TC002694.

Faccenna, C., Piromallo, C., Crespo-Blanc, A., Jolivet, L., Rossetti, F., 2004. Lateral slab deformation and the origin of the western Mediterranean arcs. Tectonics 23, TC1012. http://dx.doi.org/10.1029/2002TC001488.

Ferrucci, F., Gaudiosi, G., Pino, N.A., Luongo, G., Hirn, A., Mirabile, L., 1989. Seismic detection of a major Moho upheaval beneath the Campania volcanic area (Naples, Southern Italy). Geophys. Res. Lett. 16, 1317-1320.

Finetti, I.R., Del Ben, A., 2005. Ionian Tethys lithosphere rollback sinking and back arc Tyrrhenian opening from new CROP seismic data. In: Finetti, I.R. (Ed.), 2005. CROP Project: Deep Seismic Exploration of the Central Mediterranean and Italy. Elsevier, Amsterdam, pp. 483-503.

Frepoli, A., Selvaggi, G., Chiarabba, C., Amato, A., 1996. State of stress in the Southern Tyrrhenian subduction zone from fault-plane solutions. Geophys. J. Int. 125, 879-891.

Friedman, S.J., Burbank, D.W., 1995. Rift basins and supradetachment basins: intracontinental extensional end-members. Basin Res. 7, 109-127.

Gars, G., Lippmann, M., 1984. Nouvelle doneés néotectonique dans l'Apennin cam-panien (Italie du Sud). C.R. Acad. Sc. Paris 298, 495-500.

Giacomuzzi, G., Civalleri, M., De Gori, P., Chiarabba, C., 2012. A 3D vs model of the upper mantle beneath Italy: insight on the geodynamics of central Mediterranean. Earth Planet. Sci. Lett. 335-336, 105-120.

Govers, R., Wortel, M.J.R., 2005. Lithosphere tearing at STEP faults: response to edges of subduction zones. Earth Planet. Sci. Lett. 236, 505-523.

Gvirtzman, Z., Nur, A., 1999. The formation of Mount Etna as a consequence of slab rollback. Nature 401, 782-785.

Harding, T.P., 1985. Seismic characteristics and identification of negative flower structures, positive flower structures, and positive structural inversion. Am. Assoc. Pet. Geol. Bull. 69, 582-600.

Henk, A., Nemčok, M., 2008. Stress and fracture prediction in inverted half-graben structures. J. Struct. Geol. 30 (1), 81-97.

Iannace, P., Milia, A., Torrente, M.M., 2013. 4D geologic evolution in the Gaeta Bay sedimentary infill (Eastern Tyrrhenian Sea). GeoActa 12, 25-36 (Bologna).

International Seismological Centre, 2001. Bulletin Disks 1-9 [CD-ROM]. Internatl. Seis Cent, Thatcham, UK.

Ippolito, F., Ortolani, F., Russo, M., 1973. Struttura marginale tirrenica dell'Appennino campano: reinterpretazioni di dati di antiche ricerche di idrocarburi. Mem. Soc. Geol. It. 12, 227-250.

Isacks, B., Molnar, P., 1971. Distribution of stresses in the descending lithosphere from a global survey of focal-mechanism solutions of mantle earthquakes. Rev. Geophys. Space Phys. 9, 103-174.

Jackson, C.L., Chua, S.T., Bell, R.E., Magee, C., 2013. Structural style and early stage growth of inversion structures: 3D seismic insights from the Egersund Basin, offshore Norway. J. Struct. Geol. 46, 167-185.

Kastens, K.A., Mascle, J., et al., 1987. Proc. Ocean Drilling Program, Init. Rep. 107. College Station, TX.

Koulakov, I., Sobolev, S.V., 2006. A tomographic image of Indian lithosphere break-off beneath the Pamir Hindukush Region. Geophys. J. Int. 164, 425-440.

Koulakov, I., Kaban, M.K., Tesauro, M., Cloetingh, S.A.P.L., 2009. P and S velocity anomalies in the upper mantle beneath Europe from tomographic inversion of ISC data Geophys. J. Int. 179, 345-366.

Lavecchia, G., 1988. The Tyrrhenian-Apennines system: structural setting and seismotectogenesis. Tectonophysics 147, 263-296.

Lima, A., De Vivo, B., Spera, F.J., Bodnar, R.J., Milia, A., Nunziata, C., Belkin, H.E., Cannatelli, C., 2009. Thermodynamic model for uplift and deflation episodes (bradyseism) associated with magmatic-hydrothermal activity at the Campi Flegrei (Italy). Earth Sci. Rev. 97, 44-58.

Lucente, F.P., Speranza, F., 2001. Belt bending driven by lateral bending of subducting lithosphere slab: geophysical evidences from the northern Apennines (Italy) Tectonophysics 337, 53-64.

Lucente, F.P., Chiarabba, C., Cimini, G.B., Giardini, D., 1999. Tomographic constraints on the geodynamic evolution of the Italian region. J. Geophys. Res. 104, 20307-20327.

Lucente, F.P., Margheriti, L., Piromallo, C., Barruol, G., 2006. Seismic anisotropy reveals the long route of the slab through the western-central Mediterranean mantle. Earth Planet. Sci. Lett. 241, 517-529. 
Malinverno, A., Ryan, W.B.F., 1986. Extension in the Tyrrhenian Sea and shortening in the Apennines as result of arc migration driven by sinking of the lithosphere. Tectonics 5 , 227-245.

Marani, M., Trua, T., 2002. Thermal constriction and slab tearing at the origin of a superinflated spreading ridge: Marsili volcano (Tyrrhenian Sea). J. Geophys. Res. 107 (B9), 2188. http://dx.doi.org/10.1029/2001jb000285.

Marani, M., Gamberi, G., Bortoluzzi, G., Carrara, G., Ligi, M., Penitenti, D., 2004. Seafloor morphology of the Tyrrhenian Sea. Scale 1:1,000,000. Included to: Mem. Descr. Carta Geol. Ital., LXIV. Rome.

Mariani, M., Prato, R., 1988. I bacini neogenici costieri del margine tirrenico: approccio sismo-stratigrafico. Mem. Soc. Geol. It. 41, 519-531.

Marone, F., van der Lee, S., Giardini, D., 2004. Three-dimensional upper mantle S-velocity model for the Eurasia-Africa plate boundary region. Geophys. J. 158, 109-130.

Martin, A.K., 2006. Oppositely directed pairs of propagating rifts in back arc basins: double saloon door seafloor spreading during subduction rollback. Tectonics 25, TC3008. http://dx.doi.org/10.1029/2005TC001885.

Mattei, M., Petrocelli, V., Lacava, D., Schiattarella, M., 2004. Geodynamic implication of Pleistocene ultrarapid vertical - axis rotation in the Southern Apennines, Italy. Geology 789-792 http://dx.doi.org/10.1130/G20552.1.

Mauffret, A., Frizon de Lamotte, D., Lallemand, S., Gorini, C., Maillard, A., 2004. E-W opening of the Algerian Basin (Western Mediterranean). Terra Nova 16, 257-264.

Mauro, A., Schiattarella, M., 1988. L'Unità Silentina di base: Assetto strutturale, metamorfico e significato tettonico nel quadro geologico dell'Appennino Meridionale. Memorie della Società Geologica Italiana 41, 1201-1213.

Mazzotti, A., Stucchi, E., Fradelizio, G.L., Zanzi, L., Scandone, P., 2000. Seismic exploration in complex terrains: a processing experience in the Southern Apennines. Geophysics $65,1402-1417$

Menardi-Noguera, A., Rea, G., 2000. Deep structure of the Campanian-Lucanian Arc (Southern Apennines, Italy). Tectonophysics 324, 239-265. http://dx.doi.org/10. 1016/S0040-1951(00)00137-2.

Milia, A., 1999. Aggrading and prograding infill of a peri-Tyrrhenian basin (Naples Bay Italy). Geo-Mar. Lett. 19, 237-244

Milia, A., 2000. The Dohrn Canyon formation: a response to the eustatic fall and tectonic uplift of the outer shelf (Eastern Tyrrhenian Sea margin, Italy). Geo-Marine Lett. 22, 101-108.

Milia, A., 2010. The stratigraphic signature of volcanism off Campi Flegrei (Bay of Naples, Italy). Geol. Soc. Am. Spec. Pap. 464, 155-170.

Milia, A., Torrente, M.M., 1997. Evoluzione tettonica della Penisola Sorrentina(margine peritirrenico campano). Boll. Soc. Geol. It. 116, 487-502.

Milia, A., Torrente, M.M., 1999. Tectonics and stratigraphic architecture of a peryTyrrhenian half-graben (Bay of Naples, Italy). Tectonophysics 315, 297-314.

Milia, A., Torrente, M.M., 2007. The influence of paleogeographic setting and crustal subsidence on the architecture of ignimbrites in the Bay of Naples (Italy). Earth Planet. Sci. Lett. 263, 192-206.

Milia, A., Torrente, M.M., 2011. The possible role of extensional faults in localizing magmatic activity: a crustal model for the Campanian Volcanic Zone (Eastern Tyrrhenian Sea, Italy). J. Geol. Soc. 68, 471-484.

Milia, A., Torrente, M.M., 2014. Early-stage rifting of the Southern Tyrrhenian region: the Calabria-Sardinia breakup. J. Geodyn. 81, 17-29. http://dx.doi.org/10.1016/j.jog.2014 06.001

Milia, A., Torrente, M.M., 2015a. Rift and supradetachment basins during extension: insight from the Tyrrhenian rift. J. Geol. Soc. 72, 5-8. http://dx.doi.org/10.1144/ jgs2014-046.

Milia, A., Torrente, M.M., 2015b. Tectono-stratigraphic signature of a rapid multistage subsiding rift basin in the Tyrrhenian-Apennine hinge zone (Italy): a possible interaction of upper plate with subducting slab. J. Geodyn. 86, 42-60. http://dx.doi.org/10. 1016/j.jog.2015.02.005

Milia, A., Torrente, M.M., Giordano, F., Mirabile, L., 2006. Rapid changes of the accommodation space in the Late Quaternary succession of Naples Bay, Italy: the influence of volcanism and tectonics. In: De Vivo, B. (Ed.), Volcanism of the Campania Plain: Vesuvius. Campi Flegrei and Ignimbrites. Dev. Volcanol Vol. 9, pp. 53-68.

Milia, A., Torrente, M.M., Massa, B., Iannace, P., 2013. Progressive changes in rifting directions in the Campania margin (Italy): new constrains for the Tyrrhenian Sea opening Glob. Planet. Chang. 109, 3-17. http://dx.doi.org/10.1016/j.gloplacha.2013.07.003.

Milia, A., Torrente, M.M., Russo, M., Zuppetta, A., 2003. Tectonics and crustal structure of the Campania continental margin: relationships with volcanism. Miner.Petrol. 79, 33-47.

Milia, A., Turco, E., Pierantoni, P.P., Schettino, A., 2009. Four-dimensional tectonostratigraphic evolution of the Southeastern peri-Tyrrhenian basins (Margin of Calabria, Italy). Tectonophysics 476, 41-56

Mitchum, R.M., Vail, P.R., Sangree, J.B., 1977. Seismic stratigraphy and global changes of sea level, Part 6: stratigraphic interpretation of seismic reflection patterns in depositional sequences. In: Payton, C.E. (Ed.), Seismic Stratigraphy - Application to Hydrocarbon Exploration. Am. Ass. Petr. Geol. Mem Vol. 26, pp. 117-133.

Mongelli, F., Loddo, M., Calcagnile, G., 1975. Some observations of the Apennines gravity field. Earth Planet. Sci. Lett. 24, 385-393.

Montuori, C., Cimini, G.B., Favali, P., 2007. Teleseismic tomography of the southern Tyrrhenian subduction zone: new results from seafloor and land recordings. J. Geophys. Res. 112, B03311. http://dx.doi.org/10.1029/2005JB004114.

Mostardini, F., Merlini, S., 1986. Appennino Centro Meridionale, sezioni geologiche proposta di modello strutturale. Memorie della Società Geologica Italiana 35 177-202.

Muto, T., Steel, R.J., 1997. Principles of regression and transgression: the nature of the interplay between accommodation and sediment supply. J. Sediment. Res. 67, 994-1000.

Neri, G., Orecchio, B., Totaro, C., Falcone, G., Presti, D., 2009. Subduction beneath southern Italy close the ending: results from seismic tomography. Seismol. Res. Lett. 80 (1) $63-70$.
Nicolich, R., 1989. Crustal structure from seismic studies in the frame of the European Geotraverse (Southern segment) and CROP project. In: Boriani, A., Bonafede, M., Piccardo, G.B., Vai, G.B. (Eds.), The Lithosphere in Italy. Advances in Earth Science Research. Atti Convegni dei Lincei Vol. 80, pp. 41-61.

Panza, G.F., 1984. Structure of the lithosphere-asthenosphere system in the Mediterranean region. Ann. Geophys. 2, 137-138

Patacca, E., Sartori, R., Scandone, P., 1990. Tyrrhenian basin and Apenninic arcs: kinematic relations since late Tortonian times. Memorie Società Geologica Italiana 45, 425-451.

Peccerillo, A., 2005. Plio-Quaternary Volcanism in Italy. Springer, Berlin, Heidelberg, New York (365 pp).

Piromallo, C., Morelli, A., 2003. P wave tomography of the mantle under the Alpine-Mediterranean area. J. Geophys. Res. 108 (B2), 2065. http://dx.doi.org/10.1029/ 2002JB001757.

Rosenbaum, G., Lister, G.S., 2004. Neogene and Quaternary rollback evolution of the Tyrrhenian Sea, the Apennines, and the Sicilian Maghrebides. Tectonics 23, TC1013. http://dx.doi.org/10.1029/2003TC001518.

Rosenbaum, G., Gasparon, M., Lucente, F.P., Peccerillo, A., Miller, M.S., 2008. Kinematics of slab tear faults during subduction segmentation and implications for Italian magmatism. Tectonics 27, TC2008. http://dx.doi.org/10.1029/2007TC002143.

Rosi, M., Sbrana, A. (Eds.), 1987. Phlegrean fieldsCNR, Quad. Ric. Scient. 114 (9) (175 pp).

Roure, F., Casero, P., Addoum, B., 2012. Alpine inversion of the North African margin and delamination of its continental lithosphere. Tectonics 31, TCXXXX. http://dx.doi.org/ 10.1029/2011TC002989.

Roure, F., Colletta, B., De Tonit, B., Loureirot, D., Passalacquat, H., Gout, Y., 1997. Withinplate deformations in the Maracaibo and East Zulia basins, western Venezuela. Mar. Pet Geol. 14 (2), 139-163.

Roure, F., Howell, D.G., Guellec, S., Casero, P., 1990. Shallow structures induced by deepseated thrusting. In: Letouzey, J. (Ed.), Petroleum Tectonics in Mobile Belts. Technip, Paris, pp. 15-30.

Russo, F., 1990. I sedimenti quaternari della Piana del Sele. Studio geologico e geomorfologico (con allegata una Carta Geologica a scala 1:50.000). Tesi di Dottorato, Università di Napoli, 168 pp.

Sacchi, M., Infuso, S., Marsella, E., 1994. Late-Pliocene-Early Pleistocene compressional tectonics in offshore Campania (Eastern Tyrrhenian Sea). Bollettino di Geofisica Teorica e Applicata 36 (141/144), 469-482.

Sandiford, M., 1999. Mechanics of basin inversion. Tectonophysics 305, 109-120.

Sartori, R., 1989. Drillings of ODP Leg 107 in the Tyrrhenian Sea: tentative basin evolution compared to deformations in the surroundings chain. In: Boriani, A., Bonafede, M., Piccardo, G.B., Vai, G.B. (Eds.), The Lithosphere in Italy. Accademia Nazionale Lincei Vol. 80, pp. 139-156.

Sartori, R., 1990. The main results of ODP leg 107 in the frame of neogene to recent geology of perityrrhenian areas. In: Kastens, K., Mascle, J., et al. (Eds.), Proceedings of ODP Scientific Results. 107, pp. 715-730.

Sartori, R., 2005. Bedrock geology of the Tyrrhenian Sea insight on Alpine paleogeography and magmatic evolution of the basin. In: Finetti, I.R. (Ed.), 2005. CROP Project: Deep Seismic Exploration of the Central Mediterranean and Italy. Elsevier, Amsterdam, pp. 69-80.

Schellart, W.P., Lister, G.S., 2005. The role of the East Asian active margin in widespread extensional and strike-slip deformation in East Asia. J. Geol. Soc. 162, 959-972.

Schellart, W.P., Nieuwland, D.A., 2003. 3D evolution of a pop-up structure above a doublebasement strike-slip fault: some insights from analogue modelling. In: Nieuwland, D.A. (Ed.), New Insights into Structural Interpretation and Modelling. Geol. Soc. Spec. Publ Vol. 212, pp. 169-179.

Schiattarella, M., Beneduce, P., Di Leo, P., Giano, S.I., Giannandrea, P., Principe, P., 2005. Assetto strutturale ed evoluzione morfotettonica quaternaria del vulcano del Monte Vulture (Appennino lucano). Boll. Soc. Geol. Ital. 124, 543-562.

Schlische, R.W., Olsen, P.E., 1990. Quantitative filling model for continental extensional basins with applications to Early Mesozoic rifts of Eastern North America. J. Geol. 98, 135-155

Scrocca, D., Doglioni, C., Innocenti, F., Manetti, P., Mazzotti, A., Bertelli, L., Burbi, L., D'Offizi, S., 2003. Crop Atlas Seismic Reflection Profiles on the Italian Crust. Mem. Descritt. Carta Geol. Ital. LXII pp. 1-193 (36 plates enclosed).

Selli, R., 1981. Thoughts on the Geology of the Mediterranean Region. In: Wezel, F.C. (Ed.), Sedimentary Basins of Mediterranean Margins. Tecnoprint, Bologna, pp. 489-501.

Séranne, M., 1999. The Gulf of Lion continental margin (NW Mediterranean basins: tertiary extension within the Alpine orogen, in the Mediterranean basins: tertiary extension within the Alpine Orogen, in: B. Durand et al. (Eds). Geol. Soc. Spec. Publ. 156, $15-36$.

Serri, G., 1990. Neogene-Quaternary magmatism of the Tyrrhenian Region: characterization of the magma sources and geodynamic implication. Mem. Soc. Geol. Ital. 41, 219-242.

Smith, J.F. (Ed.), 2005. Digital Geoscience Spatial Model Project Final ReportBrit. Geol. Sur. Occas. Publ. 9 (56 pp)

Song, T., 1997. Inversion styles in the Songliao basin (northeast China) and estimation of the degree of inversion. Tectonophysics 283, 173-188.

Stampfli, G., Borel, G., 2004. The TRANSMED transects in space and time: Constraints in the paleotectonic evolution of the Mediterranean domain. In: Cavazza, W., et al. (Eds.), The TRANSMED Atlas: The Mediterranean Region From Crust to Mantle. Springer, New York, pp. 53-80.

Tavarnelli, E., 1996. Ancient synsedimentary structural control on thrust ramp development: examples from the Northern Apennines, Italy. Terra Nova 8, 65-74.

Tavarnelli, E., Peacock, D.C.P., 1999. From extension to contraction in syn-orogenic foredeep basins: the Contessa section, Umbria-Marche Apennines, Italy. Terra Nova $11,55-60$.

Tavarnelli, E., Decandia, F.A., Renda, P., Tramutoli, M., Gueguen, E., Alberti, M., 2001. Repeated reactivation in the Apennine-Maghrebide system, Italy: a possible example 
of fault-zone weakening? In: Holdsworth, R.E., Strachan, R.A., Maglouglin, J.F., Knipe, R.J. (Eds.), The Nature and Tectonic Significance of Fault Zone Weakening. Geological Society of London Special Publication 186, pp. 273-286

Taylor, B., 1995. Back arc Basins. Tectonics and Magmatism. Plenum Press (524 pp).

Tesauro, M., Kaban, M.K., Cloetingh, S.A.P.L., 2008. EuCRUST-07: a new reference model for the European crust. Geophys. Res. Lett. 35, L05313. http://dx.doi.org/10.1029/ 2007 GL032244.

Torrente, M.M., Milia, A., 2013. Volcanism and faulting of the Campania margin (Eastern Tyrrhenian Sea, Italy): a three-dimensional visualization of a new volcanic field off Campi Flegrei. Bull. Volcanol. 75 (6), 1-13. http://dx.doi.org/10.1007/s00445-0130719-0.

Torrente, M.M., Milia, A., Bellucci, F., Rolandi, G., 2010. Extensional tectonics in the Campania Volcanic Zone (eastern Tyrrhenian Sea, Italy): new insights into relationship between faulting and ignimbrite eruptions. Ital. J. Geosci. 129, 297-315. http://dx. doi.org/10.3301/IJG.2010.07.

Turner, J.P., Williams, G.A., 2004. Sedimentary basin inversion and intra-plate shortening. Earth Sci. Rev. 65 (3), 277-304.

USGS seismic catalogue, d. http://earthquake.usgs.gov/earthquakes/search/.

van Hinsbergen, D.J.J., Wissers, R.L.M., Spakman, W., 2014. Origin and consequences of western Mediterranean subduction, rollback and slab segmentation. Tectonics 33. http://dx.doi.org/10.1002/2013TC003349.

ViDEPI, 2009. Progetto Visibilità Dati Esplorazione Petrolifera in Italia, (c) 2009-2010 Ministero dello Sviluppo Economico UNMIG. Società Geologica Italiana,
Assominerariahttp://unmig.sviluppoeconomico.gov.it/videpi/ Accessed 25 November 2011.

Vitale, S., Ciarcia, S., Mazzoli, S., Zaghloul, M.N., 2011. Tectonic evolution of the 'Liguride' accretionary wedge in the Cilento area, southern Italy: a record of early Apennine geodynamics. J. Geodyn. 51, 25-36.

Wernicke, B., Burchfiel, B.C., 1982. Modes of extensional tectonics. J. Struc. Geol. 4, 105-115.

Westaway, R., 1993. Quaternary uplift of Southern Italy. J. Geophys. Res. 98 (B12), 741-772.

White, N.J., Jackson, J.A., McKenzie, D.P., 1986. The relationship between the geometry of normal faults and that of the sedimentary layers in their hangingwalls. J. Struct. Geol. 8, 897-909.

Wortel, M.J.R., Spakman, W., 2000. Subduction and slab detachment in the Mediterranean-Carpathian Region. Science 290, 1910-1917. http://dx.doi.org/10.1126/ science.290.5498.1910.

Zito, G., Mongelli, F., de Lorenzo, S., Doglioni, C., 2003. Heat flow and geodynamics in the Tyrrhenian Sea. Terra Nova 15, 425-432. http://dx.doi.org/10.1046/j.1365-3121. 2003.00507.x.

Zuppetta, A., Sava, A., 1992. Pleistocene brittle deformation in the Eboli Conglomerates (Sele Plain-Campanian Apennines). Boll. Soc. Geol. It. 111, 273-281. 